\title{
BENS, MALES E (E)(E)STADOS (IN)CONSTITUCIONAIS: SOCIALIDADE E LIBERDADE(S): NOTAS SOBRE UMA PANDEMIA
}

\section{GOODS, EVILS AND (UN)CONSTITUTIONAL STATES: WELFARE AND FREEDOM(S): NOTES ON A PANDEMICS}

\author{
JOÃO CARLOS LOUREIRO ${ }^{1}$
}

RESUMO: A pandemia que se abateu sobre o mundo levanta uma multiplicidade de questões jurídicas. Privilegiando uma perspetiva constitucional, sustenta-se que: 1) As situações de emergência não têm necessariamente de ser enquadradas por via do estado de exceção; 2) Se a liberdade real aponta para dimensões de socialidade, em parte expressas em sede de direitos económicos, sociais e culturais, a socialidade é também fundamento da restrição da própria liberdade, num mundo em que cresce a diferença entre "espaço vital dominado", aquele que a pessoa controla por si, e o "espaço vital efetivo" (Forsthoff), aquele onde decorre a sua existência, cada vez mais dependente de serviços públicos, os tradicionais e os novos (v.g., Internet); 3) As respostas no plano estatal, continuando a ser decisivas (para o bem e para o mal), revelam a sua insuficiência, exigindo-se o desenvolvimento interorganizacional e internormativo (com uma zona interconstitucional). A internormatividade é, pois, modelo a aprofundar (especialmente, no caso português, na lógica dos "grandes espaços", em particular da União Europeia e da lusofonia, tendo presente o cruzamento de histórias), recusando-se um conjunto de tentações (panótica, pan-europeia, panmundial).

Palavras-Chave: Pandemia; direito constitucional; estado de exceção; socialidade; emergência; internormatividade; interconstitucionalidade.

\footnotetext{
${ }^{1}$ Instituto Jurídico da Faculdade de Direito da Universidade de Coimbra. E-mail: loureiro@fd.uc.pt.
} 
ABSTRACT: The pandemic that grips the world raises a host of legal questions. This article adopts a constitutional perspective and argues that: (1) emergency situations do not necessarily have to be framed as states of exception; (2) if actual freedom points towards welfare dimensions (to be found in part on economic, social and cultural rights), welfare is also a basis for restricting freedom, in a world with an increase in the difference between "vital space controlled" (the one controls) and "actual vital space" (Forsthoff), the one where his/her existence happens, dependent more and more on public services, traditional and new ones (e.g. Internet); (3) the answers at state level, although still decisive (for the better or for the worse), reveal their insufficiency - interorganizational and internormative development (with an interconstitutional zone) is required. Internormativity is thus a framework in need of development (especially in the Portuguese case, within a logic of "great spaces", in particular the EU and the lusophone space, given the shared history). In this context, a group of temptations (the panoptic temptation, the pan-european temptation, the universal temptation) will be refused.

Keywords: Pandemics; constitutional law; state of exception; welfare; emergency; internormativity; interconstitutionality.

Convocados para um breve apontamento, em tempos ainda sob o signo da pandemia que se abateu sobre o mundo, não nos é possível traçar densificado roteiro da multiplicidade de problemas em termos de teoria do Estado e da Constituição, desde logo (mas não apenas) por constrições temporais.

Em sede de direito constitucional, privilegiamos, de há muitoº ${ }^{2}$ uma perspetiva centrada em bens fundamentais (por exemplo, vida, integridade pessoal e saúde), juridicamente tutelados por princípios e regras e que têm expressão em posições jurídicas ${ }^{3}$. Depois da experiência da ditadura e um pouco em sintonia com o tempo - a "era (idade) dos direitos" ${ }^{4}$, os deveres fundamentais foram, com poucas exceções ${ }^{5}$, deixados nas sombras da juridicidade. Bens que podem ser postos em

\footnotetext{
${ }^{2}$ Loureiro (2003), Parte I.

${ }^{3}$ Temos os bens fundamentais como elemento que, além do mais, contribui para uma análise de direito comparado. Podem é ser protegidos de modos diferentes nas ordens constitucionais concretas. A nossa leitura não é idêntica à de Luigi Ferrajoli que vê na consideração dos bens fundamentais uma das quatro "direções" de "expansão do paradigma garantista recebido da tradição" (Ferrajoli, 2018, p. 26; mais recentemente, vd. Ferrajoli, 2020). É, no entanto, verdade que, contrariamente ao que acontece com o direito penal, o conceito de bem tem sido marcado pelo subdesenvolvimento em termos de tratamento. Em Portugal, Jorge Pereira da Silva (2018, 171-183, que reproduz um trecho de Deveres do Estado de proteção de direitos fundamentais, Lisboa: Universidade Católica Editora, 2015, p. 345-356) integra nas "coordenadas dogmáticas básicas" os bens jurídicos protegidos. Sobre este ponto, permitimo-nos remeter para Loureiro (2003, Parte I).

${ }^{4}$ Bobbio (2004). O original italiano intitula-se L' età dei diritti, Torino: G. Einaudi, 1990.

${ }^{5}$ Em Portugal, considere-se a dissertação de Nabais (1998).
} 
risco (operador que utilizamos aqui em sentido amplo, abraçando também a incerteza ${ }^{6}$, ou, num registo jurídico, compreendendo o clássico perigo ${ }^{7}$ ) por uma série de ações ou omissões, pessoais ou institucionais, tocados pelo(s) mal(es) resultante(s) dos fenómenos naturais e das ordens artificiais, mas também das ações não intencionais ${ }^{8}$.

Ulrich Beck, na sua análise da sociedade de risco ${ }^{9}$, sublinhara já uma mudança de um discurso de bens para uma evitação de males. Não que os problemas de distribuição de bens tenham desaparecido - a desigualdade continua a marcar presença e, nalgumas sociedades, agravou-se -, mas os enfrentamentos girariam agora em torno de algo negativo, isto é, de "perdas, destruições e ameaças" 10 . A outra entrada fundamental é a da mundialização, também dos riscos, sem que isto signifique o fim dos Estados nacionais. Se a Revolução de Abril e a transição para a democracia no Brasil se fizeram em parte significativa sob o signo de uma "metanarrativa emancipatória" e da utopia11, tem-se assistido à multiplicação de cenários apocalíticos ${ }^{12}$ no quadro de uma história que não se deve ler em termos da linearidade do Progresso ${ }^{13}$. Por exemplo, perante a pandemia a tecnociência comprova a sua ambiguidade: por um lado, espera-se que a resolva, idealmente

${ }^{6}$ Trata-se de uma conhecida distinção que nos surge na obra de Frank H. Knight (1921). António Barbosa de Melo (2007, p. 165-167) considera três tipos de decisões quanto à certeza: para além das decisões na certeza, que associa às decisões condicionalmente programadas de Niklas Luhmann, fala-nos de decisões sob risco e decisões na incerteza. Nas primeiras, são possíveis juízos probabilísticos quanto às alternativas em confronto; em relação às segundas - as decisões na incerteza -, nem isso é possível, devendo operar, perante uma verdadeira situação de incerteza, por via da "estratégia dos pequenos passos", adotando teorias incrementalistas (167).

7 Falamos de risco como "superconceito" que compreende o perigo, o risco e o risco residual: cf., por todos, Groß (2001, p. 362).

${ }^{8}$ Dupuy (2005, p. 98-99). De uma forma mais geral, Dupuy afirma que "as duas categorias de natureza e de artifício não bastam, é preciso uma terceira para pensar o tipo de ordem que os homens engendram pelas suas ações, mas não pelos seus desígnios (design)" (Dupuy, 2001, p. 239).

${ }_{9}^{9}$ Expressa em diferentes obras, a começar na emblemática Risikogesellschaft: auf dem Weg in eine andere Moderne, Frankfurt a. M.: Suhrkamp, 1986. Com outras indicações, permitimo-nos remeter Loureiro (2001).

${ }^{10}$ Beck (1991, p. 12).

${ }^{11}$ Outras indicações podem ver-se em Loureiro (2017a).

${ }^{12}$ Metz (2007, p. 139) fala do fim da "hibernação" da apocalítica, afirmando que, hodiernamente, esta "en tiempos de cambio radical, agudizada incertidumbre e inadvertido peligro, emprende una segunda carrera, esta vez secular de medio a medio: el mundo ilustrado se sirve de las flotantes metáforas apocalípticas para proyectarlas indiferenciadamente sobre los medios de un cataclismo último".

${ }^{13}$ Sobre a estrutura dramática da história, suscetível de uma leitura e de uma receção que vai para lá de uma chave teológica, vd. a síntese Schwager (2014), nomeadamente quando convoca Carl Friedrich von Weizsäcker (p. 341), que recusa a neutralidade da técnica, sublinhando a sua ambiguidade, por exemplo, em matéria ambiental. 
pela disponibilização de uma vacina; por outro, como sublinhou René Girard, são os "fluxos aéreos" que aceleram o processo de contágio ${ }^{14}$, que assume um profundo impacto social ${ }^{15}$. Luigi Ferrajoli fala do "carattere irreversibile delle catastrofi che minacciano il futuro dell'umanità"16, convocando as catástrofes nuclear, ambiental e ainda o risco de uma catástrofe provocada pela "ossessione per la crescita economica" ${ }^{17}$. Jean-Pierre Dupuy ${ }^{18}$, tendo presente a relevância das ações humanas não intencionais, defende um "catastrofismo esclarecido", que tome a sério a possibilidade das catástrofes para que elas não se verifiquem. Temos considerado três apocalíticas: além da nuclear e ecológica ${ }^{19}$, também a antropológica, ilustrada em projetos trans/pós-humanistas que, para alguns, serão a saída para lidar com pandemias, dado que este não será, seguramente, o último vírus com que nos confrontaremos.

Em termos de questões jusconstitucionais relevantes no que toca à pandemia, a lista é muito grande. Recordem-se, por exemplo, os problemas em sede de proteção de dados face a um conjunto de aplicações (apps) destinadas a rastrear a doença ${ }^{20}$, podendo operar como medida alternativa ao confinamento (ou, pelo menos, complementar); os limites à liberdade de circulação e as medidas de confinamento aplicáveis a pessoas infetadas ou sob fundada suspeita ${ }^{21}$ de que poderão estar infetadas $^{22}$, mas também às outras; a liberdade de exercício da profissão, com

${ }^{14}$ Girard (2011, p. 63).

${ }^{15}$ Não vamos aprofundar aqui a teoria girardiana neste ponto, que sublinha a "indiferenciação" no quadro da globalização e do processo de "porosidade das fronteiras" (64). Esta "indiferenciação" não nega a permanência de diferenças sociais, mas desafia a teoria de Samuel Huntington do "choque de civilizações" (cf., com outras indicações, a síntese de Palaver, 2013, p. 249).

${ }^{16}$ Ferrajoli (2019, p. 283).

${ }^{17}$ Ferrajoli (2019, p. 285).

${ }^{18}$ Dupuy (2002); Dupuy (2005); Dupuy (2006).

${ }^{19} \mathrm{Na}$ literatura, refere-se também que a pressão sobre a natureza está a traduzir-se em novas ocasiões para a difusão de vírus.

${ }^{20}$ Na doutrina, vd., por exemplo, Schmitz (2020, p. 4404); em Portugal, vd. agora Mariana Melo Egídio, (2020). Em relação ao problema geral da proteção de dados, vd. as intervenções da Comissão Nacional de Proteção de Dados (CNPD): especificamente sobre a app para a notificação de exposição ao risco de contágio da Covid-19, vd. as Deliberações 2020/ 262 e 2020/277.

${ }^{21} \mathrm{Na}$ Alemanha, na segunda modificação feita em 2020 à Gesetz zur Verhütung und Bekämpfung von Infektionskrankheiten beim Menschen (Infektionsschutzgesetz - IfSG), de 19 de maio, procedeu-se a uma alteração, passando a falar-se de separação (Absonderung) em vez de quarentena (Quarantäne), cobrindo quer o isolamento de doentes quer a quarentena de suspeitos (cf. Kießling, 2020).

22 Diferentemente de Novais (2020), não vemos que haja aqui qualquer inconstitucionalidade, no que toca às normas que admitem essas medidas. Ainda que, contrariamente ao Decreto presidencial, se entenda que está em causa o direito a não ser total ou parcialmente privado de liberdade (art. 27.`/2/3 CRP), de uma leitura constitucionalmente adequada resulta que a hipótese de confinamento em virtude da pandemia tem cobertura. Não sendo possível desenvolver aqui uma teoria das restrições, que esboçámos no âmbito da nossa dissertação de doutoramento, sempre diremos que há caminhos, mesmo considerando a leitura em termos de taxatividade do 
muitos a serem impedidos de o fazer simplesmente para a realização do bem comum, em nome de um esforço para evitar a morbilidade e a mortalidade associadas ao vírus; a diferença em termos de deveres de confinamento agravados em relação a idosos (com concretizações variáveis em termos de ordenamentos jurídicos, mas que, em Portugal, se centrou nas pessoas com 70 ou mais anos), a que acrescem proibições de visitas a lares ${ }^{23}$; as severas ingerências na liberdade de culto, em diferentes países ${ }^{24}$; a questão da repartição de competências entre Estado e Estados Federados ou, no caso português, entre Estado e Regiões Autónomas (lembre-se da adoção de medidas distintas nos Açores, com implicações na liberdade de circulação, tendo havido impugnação judicial por um passageiro, por via do clássico habeas corpus ${ }^{25}$ ); o direito à educação, num tempo em que as salas de aula passaram a ser virtuais e os exames à distância ${ }^{26}$ (com discussões em termos jusfundamentais).

Centraremos a nossa análise nalguns tópicos, que traduzimos em proposições, a saber:

(1) As situações de emergência não têm necessariamente de ser enquadradas por via do estado de exceção. Impõe-se encontrar uma adequada relação entre a realidade e a normatividade, tema que desenvolvemos noutro lugar ${ }^{27}$,

elenco do n. 3 do art. 27. CRP. Um primeiro é entender que esta hipótese não cai, ab initio, no âmbito de proteção da norma; a segunda passa por abraçar a via de que estaríamos perante um caso típico de interpretação teleológica (vd. Karl Larenz, 1989). Outro problema é o de saber se a concretização legislativa existente permite esta solução. Aliás, Jorge Reis Novais sustenta que "[d]a interpretação mais adequada das normas constitucionais resultaria ser apenas excecionalmente admissível o confinamento de doentes em risco iminente e atual de contaminação de outras pessoas, dado, aí, o imprescritível e colidente dever estatal de proteção da saúde das outras pessoas (art. 64ㅇำ". Ora, abrindo esta porta, trata-se de reconduzir ao dever estatal de proteção da saúde a manutenção de capacidade de prestação do sistema de saúde pública, que encontramos, aliás, embora certamente de modo não pacífico, em países (v.g., Alemanha) com uma capacidade de prestação de cuidados de saúde (especialmente no que toca a ventiladores e unidades de cuidados intensivos) mais robusta que a nossa.

${ }^{23}$ Glaab; Schwedle (2020).

${ }^{24} \mathrm{Na}$ Alemanha, assinala-se uma decisão do Tribunal Constitucional Federal sobre esta questão: vd. BVerfG, Beschluss der 2. Kammer des Ersten Senats vom 10. April 2020

$\begin{array}{llll}- & 1 & \text { BvQ } & 31 / 20\end{array}$

(https://www.bundesverfassungsgericht.de/SharedDocs/Entscheidungen/DE/2020/04/qk2020041

0_1bvq003120.html).

${ }^{25}$ Decisão do Tribunal Judicial da Comarca dos Açores (cf. Comunicado de Imprensa 16 maio 2020), disponível

https://comarcas.tribunais.org.pt/comarcas/noticia.php?com=acores\&id_noticia=690. Vd agora, em geral, Freitas (2020).

${ }^{26}$ Fischer; Dieterich (2020).

${ }^{27}$ Loureiro (2019). 
considerando, entre outras, a análise tridimensional do direito proposta por Miguel Reale ${ }^{28}$ e a metódica de Friedrich Müller ${ }^{29}$;

(2) Em relação ao bloco de legalidade de exceção, a análise do quadro normativo revela que não é imune a algumas críticas, nomeadamente na ótica do princípio da precisão e da determinabilidade das leis;

(3) Se a liberdade real aponta para dimensões de socialidade, em parte expressas em sede de direitos económicos, sociais e culturais, a socialidade é também fundamento da restrição da própria liberdade, num mundo onde cresce a diferença entre "espaço vital dominado", aquele que a pessoa controla por si, e o "espaço vital efetivo" 30 , aquele onde decorre a sua existência, cada vez mais dependente de serviços públicos, os tradicionais e os novos (v.g., Internet);

(4) As respostas no plano estatal, continuando a ser decisivas (para o bem e para o mal), revelam a sua insuficiência, exigindo-se $o$ desenvolvimento interorganizacional e internormativo (com uma zona interconstitucional). A internormatividade (incluindo a interconstitucionalidade) é, pois, modelo a aprofundar (especialmente, no caso português, na lógica dos "grandes espaços", em particular da União Europeia e da lusofonia, tendo presente o cruzamento de histórias), recusando-se um conjunto de tentações (panótica, pan-europeia, panmundial). Se os perigos do globalismo (a redução da globalização à sua dimensão económica) ${ }^{31}$ se tornaram claros, nomeadamente a excessiva dependência em relação à República Popular da China (o exemplo do material sanitário - ventiladores ou simples equipamentos de proteção - é ilustrativo), tal não significa que o acantonamento nas praças estatais seja o caminho indicado. Com efeito, a saúde, como o ambiente, é um bem público global, pelo que a tomada de decisões num só país esquece as interdependências. Num tempo marcado pela liberdade de circulação, a garantia de realização de condições de sanidade ao nível mundial é pressuposto não apenas de efetivação de um importante direito da pessoa humana, mas modo adequado de proteção dos próprios cidadãos de cada país.

\section{SOBRE A EXCEÇÃO: FACTICIDADE E NORMATIVIDADE(S)}

Na nossa contemporaneidade, é recorrente falar-se de estados ou situações de emergência, de exceção ou de sítio, com ressonâncias diferentes consoante os contextos nacionais e as circunstâncias ${ }^{32}$. Recordem-se as reservas que suscita, para

\footnotetext{
28 Reale (2003).

${ }^{29}$ Müller (2005), especialmente a parte III - Esboço de uma metódica do direito constitucional); para uma síntese, vd. Canotilho (2003, p. 1216-1217).

30 Para esta distinção Forsthoff (1975, p. 120-121).

${ }^{31}$ Beck (1998).

$32 \mathrm{Na}$ doutrina portuguesa, há uma dissertação de doutoramento centrada no estado de exceção. Falamos da obra de Jorge Bacelar de Gouveia (1999); recentemente, publicou Estado de exceção no direito constitucional: uma perspetiva do constitucionalismo democrático: teoria geral e direito
} 
muitos, a ideia de Ausnahmezustand (estado de exceção) na Alemanha, em virtude da experiência traumática do nacional-socialismo e da utilização do célebre artigo 48. -/II da Constituição de Weimar ${ }^{33}$, cujos ecos do centenário ainda ressoam. No pós-II Guerra Mundial, a Lei Fundamental (Grundgesetz) não previu um instituto semelhante, sendo necessário esperar pela sua especial circunstância de 68 para se consagrar na Lei Fundamental uma constituição da necessidade (Notstandverfassung) ${ }^{34}$. Mais recentemente, a propósito da crise económicofinanceira de 2007/2008, também se discutiu, nomeadamente em Portugal ${ }^{35}$, se essa situação de emergência financeira configuraria um estado jurídico-constitucional de exceção ainda que não tipificado. Amnon Reichman fala, inclusivamente, de "emergências de segunda geração" 36 , ilustradas na crise dos migrantes que afetou profundamente diversos países europeus e teve também um profundo impacto político. Do ponto de vista de textos constitucionais, a Grécia apresenta-se como um caso interessante de um direito constitucional de exceção dual, ilustrando um "direito de exceção diversificado" 37 em função da causa ${ }^{38}$. Com efeito, a par do núcleo duro correspondente às ameaças internas e externas à soberania e à ordem pública ${ }^{39}$, há uma disposição no art. 44. . que contempla "extraordinary circumstances of an urgent and unforeseeable need" ${ }^{40}$. Este preceito alicerça a resposta em matéria de coronavírus na Grécia, falando-se de um " "direito de emergência» atípico" ${ }^{41}$. Na Constituição húngara, também encontramos um modelo complexo, embora com algumas diferenças em relação ao texto helénico: prevê-se um "estado de perigo", pensado em sede constituinte para as hipóteses de catástrofes naturais e de acidentes industriais ${ }^{42}$, mas também estados de crise

português, Coimbra: Almedina, 2020. Já antes registem-se as monografias de Moraes (1984) e de Correia (1989).

33 Böckenförde (2017, p. 124 e 128, respetivamente notas 61 e 64).

34 17. Gesetz zur Ergänzung des Grundgesetzes (24. 6. 1968). Sobre esta "constituição da necessidade", vd., por todos, Epping (2012).

35 Vd., por exemplo, Suzana Tavares da Silva (2011, p. 66-71); Urbano (2013).

${ }^{36}$ Citado por Kouroutakis (2016).

${ }^{37}$ Colhemos a expressão num escrito de há décadas, que persiste como um texto importante para a compreensão do direito constitucional espanhol nesta matéria. Falamos da obra Cruz Villalón (1984, p. 49). Na Constituição de 1978 (art. 116. ํ), distinguem-se três figuras, a saber: estado de alarme, de exceção e de sítio.

${ }^{38}$ No caso português, a diferença não assenta na causa, mas na gravidade [cf. art. 19.o/3: “[o] estado de emergência é declarado quando os pressupostos referidos no número anterior se revistam de menor gravidade $\left.(. . .)^{\prime \prime}\right]$.

39 Art. 48. ${ }^{\circ}$ da Constituição helénica.

40 Sobre este ponto, vd. Pottakis (2014), esp. p. 188-191.

${ }^{41}$ Karavokyris (2020).

42 Art. 53. ํㅡㄹ da Constituição húngara. Sobre a controversa reação húngara, com um anexo normativo com a versão italiana de um conjunto de diplomas, vd. Preiner (2020, p. 316). Cessou a vigência do estado de perigo, mas, a partir de 18 de junho e até quase ao final do ano (18 de dezembro), 
nacional $^{43}$, de emergência ${ }^{44}$, de defesa preventiva ${ }^{45}$, estado de ameaça terrorista ${ }^{46} \mathrm{e}$ de ataque inesperado ${ }^{47}$.

Em matéria de epidemias, recorrentes na história da humanidade, encontramos, pelo menos desde há muitos séculos, legislação específica para a combater. A dúvida é se a constitucionalização da pandemia exige apenas que a panóplia normativa seja conforme à constituição, ou se a compressão das liberdades requer a utilização da figura do estado (jurídico-constitucional) de exceção ${ }^{48}$, ao menos num quadro em que a lei fundamental, como acontece em Portugal, inclui no elenco de indicações a "calamidade pública"49.

O problema é tanto mais pertinente quando não apenas internamente - como veremos, ao analisar a Lei de Bases da Proteção Civil, que distingue diversas situações (de alerta, de contingência e de calamidade) -, mas, olhando para lá das fronteiras, externamente, deparamos com a reação normativa à pandemia por via de mobilização de um conjunto de instrumentos infraconstitucionais ${ }^{50}$. Com efeito, tradicionalmente, para lidar com algumas situações de emergência, há um direito de polícia, que, não tendo já o âmbito alargado da expressão no Estado de polícia (Polizeistaat $)^{51}$, nem por isso se reduz à mera associação que o normal cidadão faz a um conjunto de agentes de segurança. Direito da polícia que compreende na sua esfera o combate às epidemias. Aliás, na análise do estado de exceção, já Gomes Canotilho ${ }^{52}$ recordava a existência de um "direito de necessidade simples" (einfaches Notstandsrecht). Na verdade, haveria que distinguir aqui entre leis concretizadoras do estado (constitucional) de exceção - entre nós, a Lei n.. 44/86 (Regime do estado de sítio e do estado de emergência), de 30 de setembro ${ }^{53}$ - e as

está em vigor o "estado de alerta epidemiológica", sendo que, após 3 meses, será reavaliada a sua manutenção.

${ }^{43}$ Art. 49. da Constituição húngara.

${ }^{44}$ Art. 50. da Constituição húngara.

${ }^{45}$ Art. 51. ${ }^{\circ}$ da Constituição húngara.

46 Art. 51. \%/A da Constituição húngara.

47 Art. 52. ํ da Constituição húngara.

48 Retomamos e desenvolvemos o tratamento que fizemos deste tópico em Pandemia(s), Incerteza e Direito - Ciclo de Conversas em Rede - IV. Liberdades e direitos em tempos de confinamento $\cdot 2^{\underline{a}}$ parte, 13 de maio. Já a terminar este escrito foi disponibilizado o número de e-Pública 7 (2020/1) centrado no estado de exceção e crise epidémica, que só de forma parcial pôde ser considerado, especialmente em nota. Em relação a este ponto, vd. Brito (2020).

49 Art. 19.\%/2 CRP.

${ }^{50}$ Já no referido Pandemia(s), Incerteza e Direito - Ciclo de Conversas em Rede - IV, tendo presente, nomeadamente a experiência alemã, defendemos esta posição. Pedro Gonçalves (2020) apontou para o caráter excecional do uso da figura do estado constitucional de exceção nas hipóteses de calamidade pública.

51 Schiera (1984, p. 307-319).

52 Canotilho (2003, p. 1103-1104).

${ }^{53}$ Com as alterações introduzidas pelas Leis Orgânicas n. ${ }^{\text {o }}$ 1/2011, de 30 de novembro, e n.. 1/2012, de 11 de maio. 
leis que lidam com o simples direito de necessidade ${ }^{54}$, como a Lei de Proteção Civil e a Lei do Sistema de Vigilância em Saúde Pública ${ }^{55}$.

Assim, o estado (constitucional) de exceção assume caráter subsidiário, só se devendo recorrer a ele se, ao nível da legalidade conformadora dos direitos fundamentais, não for possível encontrar uma resposta. Na verdade, mesmo para quem não partilhe teses de "normalização da exceção" (no limite, à maneira de Giorgio Agamben ${ }^{56}$ ), nem sempre as fronteiras entre o normal e o excecional são claras; além disso, no que aqui nos interessa, a resposta jurídica poderá ou não ser feita por via do estado constitucional de exceção, que surge como ultima ratio para lidar com o problema. E nem se diga que, desta forma, se esvazia o estado de exceção, nomeadamente no caso de calamidade pública. Com efeito, mesmo no campo do estado jurídico-constitucional de exceção importa operar com uma metódica da diferenciação que tome a sério as distintas indicações da figura (entre nós, "agressão efetiva ou iminente por forças estrangeiras, de grave ameaça ou perturbação da ordem constitucional democrática ou de calamidade pública") ${ }^{57}$. Aliás, ao argumento avançado do esvaziamento (que não concedemos, embora reconheçamos que, na nossa leitura, o âmbito do estado jurídico-constitucional de exceção em caso de calamidades é mais confinado) pode contrapor-se o risco de banalização do instituto. Além disso, na sua relação com o âmbito normativo, com a realidade, há uma "geometria variável" de aplicação da norma, que permite cobrir escalas distintas de restrição, sem ser necessário lançar mão da suspensão de direitos ${ }^{58}$.

54 Pedro Gonçalves (2019, p. 391-392) recorda a distinção entre o "estado de necessidade administrativa" (388-398) como princípio geral do direito administrativo e "um 'direito de emergência', definido na legislação e em normas da própria Administração" (p. 391), que ilustra, inter alia, com a Lei de Bases da Proteção Civil (p. 391; também p. 392).

${ }^{55}$ Lei n. ${ }^{\circ}$ 81/2009, de 21 de agosto.

${ }^{56} \mathrm{Vd}$., especificamente, Agamben (2010). Face à pandemia, Agamben começou por defender que se trataria de uma "invenção" que permitiria a manutenção do "estado de exceção", que ataca as liberdades. Estes textos estão agora disponíveis em livro, tendo sido publicada tradução brasileira: cf. Agamben (2020). No Brasil, estes escritos foram objeto de um vivo debate: vd., a título de exemplo, o artigo de Yara Frateschi (2020). Paolo Flores D'Arcais publicou em Micromega uma devastadora crítica com o sintomático título os "delírios de Agamben": "Filosofia e virus: le farneticazioni di Giorgio Agamben" (http://temi.repubblica.it/micromega-online/filosofia-e-virusle-farneticazioni-di-giorgio-agamben/).

${ }^{57}$ Art. 19..$/ 2$ CRP.

${ }^{58}$ Não aprofundaremos aqui este instituto: cf., entre nós, inter alii, Jorge Miranda (2017), considerando que "a suspensão, provocada por situações de necessidade, atinge um direito a título transitório, equivale a um eclipse" (p. 383); Andrade (2019, p. 310-312), que, em nota, questiona "que se trate de uma verdadeira «suspensão» dos direitos", escrevendo: "parece que os direitos não focam propriamente suspensos, mas antes «enfraquecidos» $(\ldots)$ ". 
O combate às epidemias insere-se numa tarefa de prevenção, parte essencial de um direito de polícia ${ }^{59}$. Em Portugal, mesmo antes da declaração do estado (constitucional) de emergência, pelo Decreto do Presidente da República n. ${ }^{\circ}$ 14$\mathrm{A} / 2020$, de 18 de março ${ }^{60}$, foram introduzidas restrições por via do Decreto-Lei n.o 10-A/2020, de 13 de março ${ }^{61}$, objeto de um significativo número de alterações. Além disso, tinha sido já declarada a situação de alerta em todo o território nacional ${ }^{62}$.

\section{O BLOCO LEGISLATIVO DO "DIREITO DE NECESSIDADE SIMPLES"}

A admissibilidade de um "direito de necessidade simples" como fundamento de intervenção no combate às epidemias não significa que, sem mais, estejam cumpridos os requisitos constitucionais, tais como como o princípio da proibição do excesso, o princípio da igualdade ${ }^{63}$ e o princípio da precisão e determinabilidade das normas jurídicas ${ }^{64}$. Em relação a este último, uma das exigências do tipo Estado Constitucional enquanto Estado de direito assenta na clareza das normas e, no que aqui especialmente nos importa, de uma concretização ou densificação que afaste o temido arbítrio. Não basta, pois, que seja observada a forma de lei nas restrições de direitos, liberdades e garantias. É necessário que se respeite o princípio da precisão e determinabilidade das leis, ou seja, há obrigações de densificação normativa que são vistas como requisitos da constitucionalidade das normas enquanto estabelecem critérios de conduta e consequentes medidas de controlo. Ora, sob este ponto de vista, levantaram-se, em vários países, dúvidas sobre a suficiência da moldura normativa ${ }^{65}$. A questão vale para o direito português, com um quadro normativo ainda mais rarefeito do que o de outros ordenamentos.

\footnotetext{
${ }^{59}$ Basta consultar uma obra clássica do direito administrativo português: falamos do Manual de direito administrativo, de Marcello Caetano (t. II, Lisboa: ${ }^{9} 1972$, p. 1165-1167) que, no âmbito da polícia sanitária, considera, além da polícia bromatológica e da polícia médica, a polícia higiénica. Ao tratar do combate às epidemias, sublinha "que pode assumir o caráter da proclamação de um verdadeiro «estado de sítio» sanitário com cordões de isolamento da região contaminada (...)" (p. 1166).

${ }^{60}$ Fundado, nos termos constitucionalmente exigidos, na autorização da Assembleia da República (Resolução n. ${ }^{\circ}$ 15-A/2020, de 18 de março), renovada por duas vezes: Resolução da Assembleia da República n.․․ 22-A/2020, de 2 de abril, e Resolução da Assembleia da República n.ำ 23-A/2020, de 17 de abril.

${ }^{61}$ Estabelece medidas excecionais e temporárias relativas à situação epidemiológica do novo Coronavírus - COVID 19. Cf. também a Lei n.. 1 -A/2020, de 19 de março, que procedeu, conforme resulta do art. 1.\%/a), à ratificação dos efeitos do mencionado Decreto-Lei n. ${ }^{\circ}$ 10-A/2020, de 13 de março (diploma sucessivamente alterado). A Lei n. ${ }^{\circ}$ 4-A/2020 e a Lei n.. $4-\mathrm{B} / 2020$, ambas de 6 de abril, bem como as Leis n. ${ }^{\text {os }}$ 14/2020, de 9 de maio, e a Lei n. ${ }^{\circ}$ 16/2020, de 29 de maio, introduziram alterações à Lei n.o $1-\mathrm{A} / 2020$.

${ }^{62}$ Despacho n.. 3298-B/2020, de 13 de março. Não iremos aqui considerar as intervenções específicas das Regiões Autónomas dos Açores e Madeira: para outras informações, vd. Freitas (2020).

${ }^{63}$ A socióloga Eva Illouz (2020) questiona o diferente tratamento em Israel, em termos de utilização do espaço público, entre as orações (permitidas) e as aulas de ioga (proibidas).

${ }^{64}$ Para uma síntese, vd. Canotilho (2003, p. 258).

${ }^{65}$ Veja-se, paradigmaticamente, o debate alemão, espelhado em textos referidos neste artigo.
} 
Procedamos a uma breve análise, começando pela Lei do Sistema de Vigilância em Saúde Pública (LVSP). No art. 17.ํ, estabelece-se um poder excecional:

1 - De acordo com o estipulado na base xx da Lei n.. $48 / 90$, de 24 de agosto, o membro do Governo responsável pela área da saúde pode tomar medidas de exceção indispensáveis em caso de emergência em saúde pública, incluindo a restrição, a suspensão ou o encerramento de atividades ou a separação de pessoas que não estejam doentes, meios de transporte ou mercadorias, que tenham sido expostos, de forma a evitar a eventual disseminação da infeção ou contaminação.

Onde se lê a base XX da Lei n. ${ }^{\circ}$ 48/90 deve ler-se agora, no quadro da nova Lei de Bases da Saúde (LBS; Lei n..$^{95 / 2019}$, de 4 de setembro), base 34, relativa à autoridade de saúde. Dispõe-se no artigo:

1 - À autoridade de saúde compete a decisão de intervenção do Estado na defesa da saúde pública, nas situações suscetíveis de causarem ou acentuarem prejuízos graves à saúde dos cidadãos ou das comunidades, e na vigilância de saúde no âmbito territorial nacional que derive da circulação de pessoas e bens no tráfego internacional.

2 - Para defesa da saúde pública, cabe, em especial, à autoridade de saúde:

a) Ordenar a suspensão de atividade ou o encerramento dos serviços, estabelecimentos e locais de utilização pública e privada, quando funcionem em condições de risco para a saúde pública;

b) Desencadear, de acordo com a Constituição e a lei, o internamento ou a prestação compulsiva de cuidados de saúde a pessoas que, de outro modo, constituam perigo para a saúde pública;

c) Exercer a vigilância sanitária do território nacional e fiscalizar o cumprimento do Regulamento Sanitário Internacional ou de outros instrumentos internacionais correspondentes, articulando-se com entidades nacionais e internacionais no âmbito da preparação para resposta a ameaças, deteção precoce, avaliação e comunicação de risco e da coordenação da resposta a ameaças;

d) Proceder à requisição de serviços, estabelecimentos e profissionais de saúde em casos de epidemias graves e outras situações semelhantes.

3 - Em situação de emergência de saúde pública, o membro do Governo responsável pela área da saúde toma as medidas de exceção indispensáveis, se necessário mobilizando a intervenção 
das entidades privadas, do setor social e de outros serviços e entidades do Estado.

O Decreto-Lei n.․ 82/2009, de 9 de abril, expressamente mencionado no DecretoLei n. ${ }^{\circ}$ 10-A/2020, de 13 de março, estabelece no seu art. 5º:

1 - As autoridades de saúde asseguram a intervenção oportuna e discricionária do Estado em situações de grave risco para a saúde pública, competindo-lhes, ainda, a vigilância das decisões dos órgãos e serviços operativos do Estado em matéria de saúde pública.

2 - Para efeitos do disposto no número anterior, as autoridades de saúde podem utilizar todos os meios necessários, proporcionais e limitados aos riscos identificados que considerem prejudiciais à saúde dos cidadãos ou dos aglomerados populacionais envolvidos. 3 - Às autoridades de saúde compete, em especial, de acordo com o nível hierárquico técnico e com a área geográfica e administrativa de responsabilidade:

a) Vigiar o nível sanitário dos aglomerados populacionais, dos serviços, estabelecimentos e locais de utilização pública e determinar as medidas corretivas necessárias à defesa da saúde pública;

b) Ordenar a interrupção ou suspensão de atividades ou serviços, bem como o encerramento dos estabelecimentos e locais referidos na alínea anterior onde tais atividades se desenvolvam em condições de grave risco para a saúde pública;

c) Desencadear, de acordo com a Constituição e a lei, o internamento ou a prestação compulsiva de cuidados de saúde a indivíduos em situação de prejudicarem a saúde pública;

d) Exercer a vigilância sanitária no território nacional de ocorrências que derivem do tráfego e comércio internacionais;

e) Proceder à requisição de serviços, estabelecimentos e profissionais de saúde em caso de epidemias graves e outras situações semelhantes.

4 - Quando ocorram situações de emergência grave em saúde pública, em especial situações de calamidade ou catástrofe, o membro do Governo responsável pela área da saúde toma as medidas necessárias de exceção que forem indispensáveis, coordenando a atuação dos serviços centrais do Ministério com as instituições e serviços do Serviço Nacional de Saúde e as autoridades de saúde de nível nacional, regional e municipal.

Voltando à LBS, na Base 35, considera-se especificamente a defesa sanitária das fronteiras, tratando-se não apenas da questão da importação de doenças, mas 
também da prevenção da sua exportação, tendo presentes a vinculação internacional em matéria de defesa sanitária e os deveres daí decorrentes na esfera de competência de cada Estado.

Aplica-se também, à semelhança de outros países e da União Europeia ${ }^{66}$, legislação referente à proteção civil, que, aliás, expressamente faz esta ponte. $\mathrm{Na}$ verdade, é a LVSP que remete para este diploma ${ }^{67}$. Na discussão travada em Portugal, identificámos duas críticas: a) fora do estado (constitucional) de exceção, apenas poderiam ser contemplados riscos territorialmente limitados, não podendo ser aplicada com alcance nacional; b) desadequação da lei de proteção civil para responder às questões epidemiológicas.

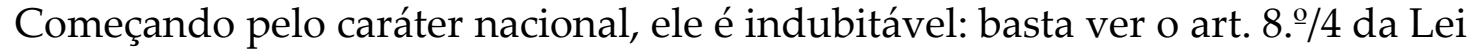
de Bases da Proteção Civil (LPC), que dispõe:

A declaração de situação de alerta, de situação de contingência e de situação de calamidade pode reportar-se a qualquer parcela do território, adotando um âmbito inframunicipal, municipal, supramunicipal, regional ou nacional.

Além disso, no art. 3. ${ }^{\circ}$, em termos de definições, lê-se:

Catástrofe é o acidente grave ou a série de acidentes graves suscetíveis de provocarem elevados prejuízos materiais e, eventualmente, vítimas, afetando intensamente as condições de vida e o tecido socioeconómico em áreas ou na totalidade do território nacional" (itálico nosso).

A declaração de estado (situação) de calamidade está sujeita à observância do princípio da subsidiariedade, só se podendo dela lançar mão se os patamares anteriores (situações de alerta e contingência) não se revelarem adequados ${ }^{68}$, exigindo-se "medidas de caráter excecional destinadas a prevenir, reagir ou repor a normalidade das condições de vida nas áreas atingidas pelos seus efeitos" ${ }^{69}$.

No art. 21..$^{\circ}$ LPC, dispõe-se:

1 - A resolução do Conselho de Ministros que declara a situação de calamidade menciona expressamente:

${ }^{66} \mathrm{Na}$ verdade, no Relatório da Comissão ao Parlamento Europeu e ao Conselho, Relatório sobre a aplicação da Decisão n. ${ }^{\circ}$ 1082/2013/UE do Parlamento Europeu e do Conselho, de 22 de outubro de 2013, relativa às ameaças sanitárias transfronteiriças graves e que revoga a Decisão n.o 2119/98/CE, a propósito do ébola, diz-se que, a pedido da OMS, foi então ativado o Mecanismo de Proteção Civil da União (p. 10).

${ }^{67}$ Art. 18..

${ }^{68}$ Art. 8. $\% 3$ LPC.

${ }^{69}$ Art. 9. $\%$ / LPC. 
a) A natureza do acontecimento que originou a situação declarada;

b) O âmbito temporal e territorial;

c) $\mathrm{O}$ estabelecimento de diretivas específicas relativas à atividade operacional dos agentes de proteção civil e das entidades e instituições envolvidas nas operações de proteção e socorro;

d) Os procedimentos de inventariação dos danos e prejuízos provocados;

e) Os critérios de concessão de apoios materiais e financeiros.

2 - A declaração da situação de calamidade pode ainda estabelecer:

a) A mobilização civil de pessoas, por períodos de tempo determinados;

b) A fixação, por razões de segurança dos próprios ou das operações, de limites ou condicionamentos à circulação ou permanência de pessoas, outros seres vivos ou veículos;

c) A fixação de cercas sanitárias e de segurança;

d) A racionalização da utilização dos serviços públicos de transportes, comunicações e abastecimento de água e energia, bem como do consumo de bens de primeira necessidade".

Será que este quadro legislativo, matéria de reserva relativa de competência legislativa da Assembleia da República, cumpre as exigências constitucionais, nomeadamente o princípio da precisão e da determinabilidade das leis? $\mathrm{Na}$ Alemanha, não se lançou mão do estado (constitucional) de exceção, que, em sentido próprio, não cobre as catástrofes, mas estas têm disciplina normativa na Lei Fundamental. Com efeito, o art. 35.//II/III da Lei Fundamental (Grundgesetz) contempla as hipóteses de "cataclismos ou catástrofes especialmente graves", havendo outros preceitos especificamente pertinentes (referem as epidemias) como o art. 11. $\% / 2$, sobre a liberdade de circulação e permanência, e o art. 13. $\% / 3$, relativo à inviolabilidade do domicílio ${ }^{70}$. Em relação ao estado de exceção, a possibilidade da situação se enquadrar na previsão constitucional do "estado interno de emergência"71 tem sido afastada ${ }^{72}$, registando-se, assim, diferenças entre o quadro constitucional português e alemão, sem que, por si só, a experiência alemã deva ser descurada, bem pelo contrário. A reação assentou na normação relativa ao combate às epidemias ${ }^{73}$, efetivada por via regulamentar, falando-se mesmo de um "estado de exceção regulamentado" (verordnete Ausnahmezustand) ${ }^{74}$. Na Lei Fundamental

${ }^{70}$ Aprofundando a distinção entre catástrofe e necessidade numa ótica constitucional, vd. Stober; Eisenmenger, (2005, p. 122).

${ }^{71}$ Art. 91. $\mathrm{o}$ da Lei Fundamental

${ }^{72}$ No entanto, Thielbörger e Behlert (2020) sustentam que a aplicação desta norma não está afastada na hipótese de pandemia, caso "verosivelmente" se configure uma situação de rutura do sistema público de saúde.

${ }^{73}$ Aliás, concretizadas por via regulamentar em cada um dos Estados federados: na doutrina, vd., por exemplo, Gärditz; Abdulsalam (2020 p. 93-140).

${ }^{74}$ Mayen (2020, p. 828-834). 
(Grundgesetz), estamos perante competências, em primeira linha, dos Estados Federados (Länder $)^{75}$, encontrando-se uma referência expressa às epidemias a propósito da liberdade de circulação e permanência ${ }^{76}$. Relativamente à Infektionsschutzgesetz, afirma-se que os artigos 28/1 e 42 são "inevitavelmente muito amplos"77. Questiona-se se a exigência constitucional de o Parlamento decidir as questões essenciais (reserva de Parlamento), com os requisitos de publicidade e de legitimação associados, não é desrespeitada por estas normas, que têm uma concretização maior que as suas equivalentes em Portugal e também a consequente mudança de eixo do legislativo para o executivo (no caso alemão, no plural, dadas as competências dos Länder) ${ }^{78}$. Consagra-se uma cláusula geral no $§ 28$ (e esta é uma técnica recorrente em legislações deste tipo, em vez de formulações "casuísticas"79). $\mathrm{Na}$ Alemanha, adotou-se, por via das alterações decorrentes da Gesetz zum Schutz der Bevölkerung bei einer epidemischen Lage von nationaler Tragweite, de 27 de março de 2020, um caminho de especificação, que, ainda assim, não escapou à crítica de insuficiência ${ }^{80}$. Portugal deveria trilhar esta senda, enfraquecendo os argumentos dos que, mesmo admitindo a legitimidade de um conjunto de medidas sem declaração de estado de exceção, sustentam a inconstitucionalidade de algumas soluções, por falta de previsão legal expressa. Mas a utilização de uma cláusula geral em matéria tão sensível em termos jusfundamentais continua a ser censurada por parte da doutrina: "quanto mais intensa for a ingerência nos direitos fundamentais, mais precisa e diferenciada deve ser a regulação" ${ }^{\prime 1}$. Ainda assim, na Alemanha, a jurisprudência sustentou que, com base na cláusula geral, seriam legítimas as proibições de entrada (Betretungsverbote ${ }^{82}$ ), no caso numa escola ${ }^{83}$.

É verdade que, de acordo com o critério adotado pela jurisprudência constitucional alemã, é necessário considerar as especificidades do domínio de regulação. Mesmo tendo presente isso, sempre se pode afirmar que é possível ao legislador parlamentar ir mais longe em termos de previsão (por exemplo, consagrar no leque de possibilidades a obrigatoriedade de emprego da máscara). Assim, só não serão inconstitucionais algumas medidas se o bloco de normatividade relevante não se abrir, nomeadamente tendo presente a existência de corpos densificados em diferentes áreas mais ligadas à técnica e à biomedicina.

\footnotetext{
75 Art. 30. ${ }^{\circ}$, conjugado com o art 70. e seguintes da Lei Fundamental (Grundgesetz).

76 Art. 11. $\% / 2$ da Lei Fundamental (Grundgesetz).

77 Papier (2020), p. 181.

78 Papier (2020). Uma anotação ao § 28 pode ver-se em Häberle; Lutz (2020).

${ }^{79}$ Em relação à contraposição entre cláusulas gerais e formulações "casuísticas", vd. Engisch ( ${ }^{91997,}$ p. 156-157).

${ }^{80}$ Gärditz; Abdulsalam (2020, p. 113).

81 Siegel (2020, p. 581-582): “Je intensiver in Grundrechte eingegriffen wird, desto genauer und differenzierter muss eine Regelung sein".

82 BVerwGE 142, 205 = NJW 2012, 2823 (2826).

${ }^{83}$ BVerwG, Urt. v. 22. 3. 2012 - 3 C 16/11 (OVG Lüneburg).
} 
Importa, no entanto, saber se o facto de haver aqui um quadro científico para o qual se remete não acaba por funcionar como um sucedâneo da densificação da lei, salvando a constitucionalidade dos preceitos de combate à epidemia. Num mundo com traços pós-vestefalianos no campo da saúde, com dimensões de "sobrecentração na humanidade" 84 , onde a Organização Mundial de Saúde (OMS) adquiriu outro peso, a adoção de um conjunto de medidas que correspondem a standards internacionais, sem prejuízo de concretizações mais ou menos restritivas no plano nacional, apresenta-se como um complemento de densificação. Ou seja, tal como se aceitaram fórmulas como "estado da técnica", aqui as medidas, desde que se insiram na paleta de respostas epidemiológicas específicas, seriam admissíveis e não haveria violação do princípio da proibição ou determinabilidade das leis. Aliás, assistiu-se a uma mimesis legislativa, expressamente reconhecida, por exemplo, no Decreto n. ${ }^{-}$14-A/2020, de 18 de março, ao defender-se a necessidade de adotar em Portugal "idênticas medidas [às de outros países europeus] de forte restrição de direitos e liberdades, em especial no que respeita aos direitos de circulação e às liberdades económicas, procurando assim prevenir a transmissão do vírus".

Mesmo a aceitar-se que a remissão para um corpo internacional, conjugada com as normas de um "direito de necessidade simples", poderá ser globalmente salvífica, daí não decorre: 1) que todas as medidas possam ser cobertas (o que exige uma analítica a que não poderemos proceder agora); 2) que uma densificação legislativa no plano nacional e tendo presente a reserva parlamentar seja desprovida de sentido, sendo, para além de tudo o mais, um caminho cautelar no que toca à (in)constitucionalidade. Dada a publicidade própria da atividade parlamentar e o pluralismo ${ }^{85}$, não admira que, sem prejuízo de deixar especificidades para um nível infralegislativo, seja recomendável que os parlamentos assumam, por inteiro, as suas responsabilidades, nomeadamente procedendo à especificação de um conjunto de medidas que devem figurar expressamente no leque de respostas.

No caso português, pelo Despacho n. ${ }^{\circ}$ 3298-B/2020, de 13 de março, procedeuse à Declaração de situação de alerta em todo o território nacional, aplicando um conjunto de restrições ${ }^{86}$ e estabelecendo um agravamento das sanções ${ }^{87}$. Pouco

${ }^{84}$ Tomamos de empréstimo uma formulação de Chardin (2008), que aplicamos no campo jurídico: cf., com outras indicações sobre o paradigma pós-vestefaliano, o que escrevemos em Loureiro (2008, p. 35-73), considerando, na altura, precisamente a síndrome respiratória aguda (SARS).

${ }^{85}$ Mobilizando este argumento, vd., por exemplo, Gärditz; Abdulsalam (2020, p. 109-110).

${ }^{86}$ N.. 3: "No âmbito da situação de alerta, determina-se a adoção das seguintes medidas, de carácter excecional: (...) b) Interdição da realização de eventos, de qualquer natureza, em recintos cobertos que, previsivelmente, reúnam mais de 1000 pessoas e ao ar livre com, previsivelmente, mais de 5000 pessoas; c) Suspensão do funcionamento dos estabelecimentos de restauração e de bebidas que disponham de salas ou de espaços destinados a dança".

87 "7 - A desobediência e a resistência às ordens legítimas das entidades competentes, quando praticadas em situação de alerta, constituem crime e são sancionadas nos termos da lei penal, sendo as respetivas penas agravadas em um terço, nos seus limites mínimo e máximo, nos termos do n. 4 do artigo 6. ${ }^{\circ}$ da Lei de Bases da Proteção Civil". 
depois, tivemos a já referida Declaração do estado (constitucional) de emergência, que, como vimos, foi prorrogada. Posteriormente foram usadas, primeiro a declaração de situação de calamidade ${ }^{88} \mathrm{e}$, mais tarde, simultaneamente, não só de situação de calamidade, mas também de contingência e alerta, em termos diferenciados no que toca ao território nacional ${ }^{89}$.

\section{SOCIALIDADE E LIBERDADE}

Consideremos agora a terceira proposição: se a liberdade real aponta para dimensões de socialidade, em parte expressas em sede de direitos económicos, sociais e culturais, a socialidade $e^{90}$ é também fundamento da restrição da própria liberdade, num mundo onde aumenta a diferença entre "espaço vital dominado", aquele que a pessoa controla por si, e o "espaço vital efetivo" ${ }^{91}$, crescentemente tecido por uma rede de serviços de interesse comum. Na verdade, contra o modelo de um desencarnado individualismo prisioneiro de uma mera igualdade formal, tornouse claro que o Estado Constitucional é um Estado social, procurando assegurar uma realização efetiva das liberdades. Se quisermos, socorrendo-nos de Amartya Sen ${ }^{92}$, trata-se de não ficar prisioneiro de uma conceção baseada nos recursos e privilegiar a sua possibilidade de transformação em funcionamentos. A “ideia de justiça” de Sen assenta numa análise a partir de capacidades ou potencialidades (capabilities). Escreve: "A noção de capacidade está ligada àquela de liberdade substantiva e, por isso, irá dar um papel central à real aptidão que uma pessoa tenha para fazer diferentes coisas cuja realização considere valiosa" ${ }^{\prime 93}$.

Na sua leitura das "fontes de variação" 94 da transformação dos rendimentos em possibilidade efetivas de vida, inclui no elenco, além das "heterogeneidades pessoais" (por exemplo, uma maior vulnerabilidade à doença), das "diversidades do meio físico" e das "diferenças nas perspetivas relacionais", também as "variações no clima social" 95 . Ora, nestas integram-se "os cuidados de saúde públicos e a epidemiologia" 96 e este ponto é o que agora nos importa considerar. Com efeito, o acesso aos referidos cuidados aparece como uma das concretizações do direito à proteção da saúde e aponta para uma dimensão institucional. Nos

\footnotetext{
${ }^{88}$ Resolução do Conselho de Ministros n.․ 33-A/2020, de 30 de abril.

${ }^{89}$ Resolução do Conselho de Ministros n. ${ }^{\circ}$ 51-A/2020, de 26 de junho.

${ }^{90} \mathrm{~A}$ socialidade recobre diferentes usos, desde a sociabilidade - que lemos em chave constitutiva e não meramente aditiva, a partir de uma teoria relacional - à socialidade no sentido de um conjunto de bens fundamentais no qual se insere a saúde. Vd., em síntese, Loureiro (2019).

${ }^{91}$ Forsthoff $(1975$, p. 120).

${ }^{22}$ Sen (2012, p. 345-346), defendendo "uma fundamental alteração do foco de atenção, que dos meios pelos quais se vive passa para as reais oportunidades de que uma pessoa dispõe (...)" (p. 345; em itálico no original).

${ }_{93}$ Sen $(2012$, p. 345).

${ }_{94}$ Sen (2012, p. 347).

${ }^{95}$ Sen (2012, p. 347-348).

${ }^{96}$ Sen (2012, p. 348).
} 
textos constitucionais de Portugal e no Brasil, esta tem como modo de expressão nuclear, respetivamente, o Serviço Nacional de Saúde (SNS ${ }^{97}$ e o Sistema Único de Saúde (SUS) ${ }^{98}$.

Simplesmente, esta faceta prestacional com tutela jusfundamental, se realiza a liberdade concreta das pessoas - na ausência de acesso ou em caso de cuidados deficientes pode estar em jogo a própria vida -, acaba por ter - e o caso do coronavírus é paradigmático - um impacto em termos de liberdades. Ou seja, no que toca à saúde pública, é fundamental garantir a capacidade do sistema para lidar com a pandemia. Não se trata apenas de um dever de prestação do Estado traduzido numa adequada provisão dos serviços, mas de uma obrigação das pessoas em contribuir para ela. Na CRP, encontramos, além do direito à proteção da saúde, o "dever de a proteger e promover", com assento constitucional no art. 64. /1 da CRP. Não é aqui o lugar para uma reflexão mais geral sobre a questão dos deveres fundamentais, nem sequer de um tratamento mais desenvolvido deste dever específico ${ }^{99}$. Um motivo-diretor das políticas de confinamento passou por retardar a propagação e ganhar tempo para reforçar as referidas capacidades sistémicas.

Quanto a esta síndrome (SARS-CoV-2), importa tornar claro que:

a) O dever de confinamento especial estabelecido em relação, por exemplo, às pessoas com 70 ou mais anos ${ }^{100}$ não decorre de uma proteção contra si próprio, pois, caso se verifiquem os pressupostos da autonomia, esta não pode deixar de ser garantida;

b) O fundamento que legitimou as restrições mais rigorosas em relação ao resto da população baseou-se no facto de, na hipótese de serem infetados, poderem afetar significativamente a capacidade do sistema de saúde, com utilização desproporcional de recursos, especialmente de ventiladores, que são escassos ${ }^{101}$, pondo em risco a vida e a saúde de outros enfermos com SARS-CoV-2 ou outras patologias.

Assim se compreende que, em relação a não infetados mais idosos, a prevenção do contágio não apareça nem como o resultado de uma inadmissível proteção contra si próprio - o especial cuidado só pode passar pela informação que tome em consideração os riscos acrescidos - nem como uma prevenção de contágio dos outros (o que já resultaria do caráter relacional do direito, não sendo necessária a autonomização de um dever) - não há um grau agravado de transmissibilidade -,

\footnotetext{
97 Art. 64. ${ }^{\circ} / 2$ CRP.

98 Art. 198. ${ }^{\circ}$ e 200. CRFB.

${ }^{99}$ Sobre estes pontos, remetemos para Loureiro (2003, Vol. I (Parte II) e Vol. II (Parte IV).

100 Em Portugal, vd. o art. 4. /1/a), do Decreto n.. 2-A/2020, de 20 de março.

101 Não aprofundaremos este tópico, mas as pandemias podem contribuir para uma escassez agravada em sede de prestação de cuidados de saúde (não limitadas a esse campo, mas afetando outras áreas da saúde) e podendo, no limite, contribuir para a multiplicação de "escolhas trágicas" (Calabresi; Bobbitt, 1978).
} 
mas simplesmente como salvaguarda da capacidade de funcionamento sistémico dos cuidados de saúde.

\section{INSUFICIÊNCIA(S) DE UMA PROTEÇÃO MERAMENTE ESTATAL NO QUADRO DE UMA "SOCIEDADE MUNDIAL DE RISCO": SOBRE A INTERNORMATIVIDADE}

Apesar da relevância e da imprescindibilidade da realização dos direitos no nível de cada entidade nacional, este plano revela-se insuficiente numa "sociedade mundial de risco". A defesa de um reforço da governança no campo da saúde (com uma pluralidade de atores, incluindo entidades não-governamentais) em termos globais como modo de resposta às pandemias é recorrente na literatura e confirmámos agora que não foram tomados a sério os avisos sobre o aparecimento, mais cedo ou mais tarde, de novas doenças provocadas por vírus ${ }^{102}$. Governança e não governo de um Estado mundial (panmundialismo). Na discussão em torno da globalização e da constituição mundial, não é esse o cenário que verdadeiramente assume relevo. Com efeito, a ideia de Estado mundial anda associada também a distopias: recordem-se obras como A modern utopia, de H.G. Wells ${ }^{103}$, ou Brave new world, de Aldous Huxley ${ }^{104}$.

$\mathrm{Na}$ sua tradução constitucional, convocamos três ideias: a) a visão da constituição como Fernverfassung (constituição à/da distância); b) a tese de que a constituição é uma categoria com potencialidades para lá do Estado (no que aqui especialmente nos importa, no plano global e ao nível da UE); c) o desenvolvimento de uma rede de internormatividade, incluindo também a interconstitucionalidade.

Começando pela primeira, num texto publicado há mais de 20 anos, em diálogo com Hans Jonas, que defendeu a necessidade de uma "ética da distância" (Fernethik $)^{105}$, propusemos o conceito de constituição à/da distância ${ }^{106}$, cobrindo não apenas a dimensão temporal (intergeracional, nomeadamente as gerações futuras ou vindouras), mas também a distância em sentido espacial (as consequências das ações no âmbito do estreitamento do mundo). Há, na verdade, uma "desterritorialização" 107, um processo de confluências normativas "multinível" num território, falando-se mesmo de uma "territorialidade pós-soberana"108. Sed contra, não se diga que assistimos agora, no quadro do vírus, a um fechamento das fronteiras que atestaria esta territorialidade soberana. Em primeiro lugar, porque

\footnotetext{
102 Vd., por exemplo, Quammen (2020).

${ }^{103}$ H. G. Wells, A modern utopia, publicado pela primeira vez em 1905.

104 Aldous Huxley, Brave new world, original de 1932, com diversas traduções em língua portuguesa (Admirável mundo novo).

105 Vd. Jonas (2006). Vd. também Peter Kemp (1992); Dieter Birnbacher (1995, p. 143-144); José de Faria Costa, esp. 405-408; sobre a ética da distância como ética do futuro no pensamento de Hans Jonas, Garcia (2007, p. 75-89).

106 Loureiro (1999, p. 275-277).

107 Innerarity (2017, p. 325), fala de uma “ontología de la desterritorialización”.

108 Jureit; Tietze (2015).
} 
não se tratou de um processo global, mas seletivo, permitindo a circulação de mercadorias; em segundo, pois o caráter temporário afasta qualquer reedição da ideia de "Estado fechado". A ideia de constituição à distância remete-nos para discussões sobre a aplicação extraterritorial de normas da lei fundamental e para as obrigações, em termos de cooperação internacional, no quadro de uma "sociedade (mundial) de risco"109, onde a construção de segurança ou saúde num só país conhece limites acrescidos. Neste ponto, trata-se de uma abertura para uma abertura do Estado e da normatividade, sem que seja sinónimo do comunismo reinventado de Žižek - "coordenação da produção e distribuição" 110 em registo global e sem o mercado - ou do merconstitucionalismo ${ }^{111}$, que faz do mercado o ídolo motor da globalização, traduzindo-se não na defesa do mercado como elemento fundamental da ordem jurídica económica, mas numa pretensão colonizadora das outras esferas, abraçando uma "civilização de mercado"112.

Uma resposta de mundialização, também no plano da saúde, tem expressão em projetos de constitucionalização global ou mundial. De um ponto de vista constitucional, temos defendido, desde há décadas, a adequação e a sustentabilidade de uma constituição global, tendo presente a diferença entre a sociedade mundial e as sociedades nacionais, e recusando a chamada "tese da repetição" ou da "analogia doméstica" 113 que, por exemplo, procura e não encontra um demos. Constituição mundial ou global, formulação que tem coberto diferentes leituras, mas que, para nós, se apresenta como uma "rede de redes", marcada por uma pluriformidade - pluriversum constitucional, ou seja, uma constituição de constituições (incluindo uma constituição da saúde), e pluritextual -, uma plurissubjetividade constitucional (compreendendo organizações nãogovernamentais) e uma pluriposicionalidade constitucional (abarcando, v.g., também os deveres) $)^{114}$.

Desde meados da década de 90 do século passado, avançámos com um esboço de uma teoria da interconstitucionalidade, a partir de reflexões em torno da internormatividade e da leitura de Karl-Otto Apel da "comunidade de comunicação" 115 . Tratava-se de articular teses que integravam o horizonte de reflexão, cruzando a pertinência da defesa de constituições e constitucionalismos para lá do Estado até à rede e às interações. De uma forma autónoma e limitada ao domínio do direito da União Europeia, coube a Francisco Lucas Pires apresentar o

\footnotetext{
${ }^{109}$ Beck (2007).

110 Žižek (2020, p. 12). Na p. 39, lê-se: "maybe another and much more beneficent ideological virus will spread and hopefully infect us: the virus of thinking of an alternate society, a society beyond nation-state, a society that actualizes itself in the forms of global solidarity and cooperation".

111 Sobre este, vd. o que escrevemos em Loureiro (2014, p. 241-244).

112 Stephen Gill (2014, p. 29-44).

${ }^{113}$ Com outras referências bibliográficas, vd. Ferrajoli (2019, p. 113, n. 33), que utiliza a expressão

"domestic analogy" precisamente em inglês, língua em que teria sido cunhada por Hedley Bull.

114 Com outros desenvolvimentos e indicações, vd. Loureiro, (2006, esp. p. 196-211).

${ }_{115}$ Karl-Otto Apel (1994), distinguindo entre uma microesfera, uma mesoesfera e uma macroesfera (p. 72-73, sendo que a última nos remete para a humanidade").
} 
termo em Introdução ao Direito Constitucional Europeu ${ }^{116}$. Mas, seria já após a sua morte que, na sequência de conversas em Freiburg - os caminhos da Floresta Negra atravessam clareiras de pensamento -, Paulo Rangel aplicou o descritor como fio que ilumina a obra de Lucas Pires ${ }^{117}$. No diálogo académico, um impulso decisivo foi dado pela reflexão de Gomes Canotilho, que, alguns anos depois, procederia a uma análise no campo jusfundamental, cunhando interjusfundamentalidade ${ }^{118} \mathrm{e}$ projetando o discurso da interconstitucionalidade, especialmente na comunidade de língua portuguesa ${ }^{119}$.

Aplicada à nossa discussão, a interconstitucionalidade não é, de forma alguma, sinónimo de obsolescência das constituições e dos Estados nacionais. Estes revelam-se como um regaço de respostas, não apenas no controlo da epidemia, mas na garantia da sobrevivência - afinal, a segurança é tarefa fundamental do Estado na realização do bem comum ou do interesse público ${ }^{120}$. Contudo, a ideia de Fern de distância - não releva apenas na sua dimensão temporal (a questão da intergeracionalidade), mas também no espaço, numa intraterritorialização de riscos que atravessam fronteiras. Ora, esta interdependência e o facto de os Estados e as Constituições não serem mónadas implica que se tomem a sério as "constelaç(ões) pós-nacionais" 121 e as redes de internormatividade - em parte, de interconstitucionalidade - e do ponto de vista organizacional se considerem as facetas transestatais, quer no plano supranacional (União Europeia) quer na esfera mundial, onde se conjugam elementos de uma normatividade internacional com sementes cosmopolitas.

Mesmo que se entenda que não existem constituições para lá dos Estados, é indubitável o reconhecimento de uma normatividade relevante situada além do Estado nacional, que é essencial também neste domínio. Há um paradigma de direitos humanos (baseado num princípio anti-sacrificial ${ }^{122}$ ) que limita as ações dos Estados no campo da saúde, com expressão, por exemplo, no combate à pandemia ${ }^{123}$.

Pense-se, desde logo, no plano da informação e de alertas: na "sociedade de conhecimento" onde vivemos, a partilha de informação assume um lugar relevantíssimo na prevenção e no combate às pandemias. Sem prejuízo das críticas

\footnotetext{
116 Pires (1997, p. 18).

${ }_{117}$ Rangel (2000, p. 127-151), também em Rangel (2009, p. 143-178).

118 Sobre este tópico, vd. Canotilho, por exemplo (2013).

119 No Brasil, Marcelo Neves (2009) avançou com a ideia de transconstitucionalismo, a partir da razão transversal de Wolfgang Welsch. Para a discussão em torno das convergências e diferenças entre transconstitucionalismo e interconstitucionalidade, vd. Rangel (2012, p. 151-174).

${ }^{120}$ Melo (1998, p. 34), que sublinha: “[p]or via desta dimensão ético-jurídica é que o conceito de bem comum ('Gemeinwohl') se distingue do conceito de interesse público ('öffentliches Interesse')" (em itálico no original).

${ }^{121}$ Habermas (1998).

122 Dupuy (2001, p. 259).

${ }^{123}$ Negri (2018, p. 268-269).
} 
sobre a sua gestão por parte da OMS, não há dúvidas que esta desempenha um papel fundamental. Nos termos da sua constituição ${ }^{124}$, é dotada de uma competência que assenta num modelo de opt out em vez do tradicional opt in, ou seja, a regra é a vinculação dos Estados, sem necessidade de expressar uma vontade neste sentido ${ }^{125}$.

Assim, no plano mundial, há um conjunto de obrigações dessa natureza consagradas no Regulamento Sanitário Internacional (International Health Regulations) ${ }^{126}$, cuja versão revista de 2005, recebeu um grande impulso em virtude da síndrome respiratória aguda (SARS $)^{127}$. Na verdade, para além das medidas tradicionais no direito sanitário internacional no que toca ao controlo de entradas no território ${ }^{128}$, há deveres não apenas de informação, como também de avaliação, comunicação e de resposta. Em 1997, criou-se a rede GOARN (Global Outbreak Alert and Response Network), formalizada em $2000^{129}$.

Informação que, resultando da cooperação internacional, é relevantíssima num mundo onde o Estado assume funções de preceptor ou de educador ${ }^{130}$, em que a atividade informativa da administração reveste um relevo crescente nas nossas "sociedade(s) de risco(s)" 131. Há uma Agenda de Segurança da Saúde Global (Global Health Security Agenda) ${ }^{132}$.

Do ponto de vista da constituição da informação, é essencial uma dimensão pósvestefaliana. Face às falhas que, mesmo depois da revisão de 2005, o Regulamento Sanitário Internacional revelou perante vários surtos, crescem as vozes em prol da necessidade de novas alterações ${ }^{133}$.

Para além do domínio estritamente informacional, a cooperação internacional no campo das infraestruturas de saúde e de pessoal sanitário e medicamentos revela-se um elemento essencial também quando estão em causa pandemias. Ou seja, enquanto bem público global, a saúde exige o concurso dos Estados e de outros

$124 \mathrm{Vd}$. o art. 22..

125 Fidler (2004, p. 159).

126 No Brasil, vd. a versão aprovada pelo Congresso Nacional por meio do Decreto Legislativo 395/2009, publicado no DOU, de 10 de julho de 2009. Na Organização Mundial de Saúde, antecedido pelo Regulamento Sanitário Internacional de 1951 (Regulamentos Adicionais de 1955, 1956, 1960, 1963 e 1965) e pelo Regulamento Sanitário Internacional de 1969 (alterado em 1973 e 1981). A partir de 1969, temos o Regulamento Sanitário Internacional n. o 2, de 25 de julho de 1969, que entrou em vigor na ordem jurídica internacional a 1 de janeiro de 1971.

127 O processo de revisão começou em 1995 e a burocracia da OMS não o terá considerado muito relevante: cf. Aginam (2014).

${ }^{128}$ Não vamos discutir aqui se as restrições impostas por alguns países em relação a passageiros provenientes da República Popular da China violaram ou não este instrumento normativo internacional. Sobre a questão, vd. Habibi (2020).

${ }^{129}$ Fidler (2004, p. xii-xv).

130 Para esta formulação, cf. Canotilho (2002, p. 711), que se refere a Estado educativo.

131 Pedro Gonçalves (2002); na doutrina brasileira, vd. Dias (2008).

132 https://ghsagenda.org/.

${ }^{133}$ Com outras indicações, vd., por todos, Tonti (2020). 
atores, sendo a desejada vacina vista como um "bem público global" (aqui com um outro uso de bem em relação ao afirmado anteriormente) ${ }^{134}$. Isto no quadro de um constitucionalismo que tome a sério a paz ${ }^{135}$. Com efeito, as pandemias são ameaças para a paz ${ }^{136}$ e, no caso do SARS-CoV-02, o Secretário-Geral da ONU, António Guterres, afirmou-o inequivocamente:

“(...) the pandemic also poses a significant threat to the maintenance of international peace and security - potentially leading to an increase in social unrest and violence that would greatly undermine our ability to fight the disease ${ }^{\prime \prime 137}$.

Convoca-se aqui emblemático título de uma obra de Nico Stehr - "A liberdade é uma filha do conhecimento" 138 - e, neste caso, a própria vida, enquanto condição de possibilidade de todos os direitos. Conhecer a doença e as formas de proteção e aceder a meios de prevenção e até a própria possibilidade de confinamento são caminho para a sobrevivência. A constituição da OMS enfatiza que a saúde é um elemento essencial em termos de paz e segurança: “A saúde de todos os povos é essencial para conseguir a paz e a segurança e depende da mais estreita cooperação dos indivíduos e dos Estados".

E já então se podia ler: "O desigual desenvolvimento em diferentes países no que respeita à promoção de saúde e combate às doenças, especialmente contagiosas, constitui um perigo comum".

No palco global, para além da Organização Mundial de Saúde, há outras entidades relevantes em sede de enfrentamento de pandemias ${ }^{139}$, tais como a Organização para a Alimentação e Agricultura, a Organização Mundial de Comércio, a Organização Mundial de Saúde Animal e o Banco Mundial.

\footnotetext{
${ }^{134}$ WHO, 73 WHA, EU Statement: Item 3 - Report by the Director General anlässlich der 73. WHA v. 18.5.2020, https://eeas.europa.eu/headquarters/headquarters-homepage/79575/who-73rdworld-health-assembly-eu-statement-item-3-report-director-general_en.

135 Vd., entre nós, a contribuição de Canotilho (2008); na doutrina alemã, com outras indicações, Häberle (2017).

$136 \mathrm{Tal}$ foi expressamente afirmado pelo Conselho de Segurança da ONU a propósito do surto de ébola que afetou a África Ocidental, especialmente a Libéria, Guiné, Serra Leoa e Nigéria (Resolução 2177: Paz e segurança em África, 18 de setembro de 2014). Vd. também o art. 39. da Carta das Nações Unidas. Analisando o problema do coronavírus como ameaça à paz internacional, vd. Svicevic (2020).

137 "COVID-19 threatening global peace and security, UN chief warns", UN News, 10 April 2020 (https://news.un.org/en/story/2020/04/1061502).

${ }^{138}$ Stehr (2015).

${ }^{139}$ Klafki (2017, p. 169).
} 
Além disso, no que correntemente é designado como uma proteção multinível ${ }^{140}$, no caso português são convocados na rede institucional e internormativa quer o direito do Conselho da Europa quer o direito da União Europeia. Quanto ao primeiro ${ }^{141}$, a Convenção Europeia dos Direitos do Homem (agora rebatizada de Direitos Humanos) prevê, por exemplo, no art. 5.. (direito à liberdade e à segurança), entre as hipóteses de legítima privação da liberdade, "a detenção legal de uma pessoa suscetível de propagar uma doença contagiosa" ${ }^{142}$, além da derrogação das obrigações previstas na CEDH, "na estrita medida em que o exigir a situação, e em que tais providências não estejam em contradição com as outras obrigações decorrentes do direito internacional" 143 .

No que toca à União Europeia, sabe-se que a proteção da saúde tem assento na Carta de Direitos Fundamentais ${ }^{144}$ e que o Tratado sobre o Funcionamento da União Europeia (TFUE) continua a consagrar que a responsabilidade neste campo é, em primeira linha, dos Estados Membros. À União cabe, pois, uma atividade complementar, nos termos previstos no art. 168. ${ }^{\circ}$ do TFUE $^{145}$, referindo o n. ${ }^{\circ} 5$ "medidas de incentivo"146 (por exemplo, em termos de testes ${ }^{147}$ ), movendo-se em registo de cooperação e promoção ${ }^{148}$. Em termos institucionais, salienta-se a criação do Centro Europeu de Prevenção e Controlo das Doenças (ECDC - European Centre for Disease Prevention and Control) ${ }^{149}$, que foi antecedido da instituição uma rede de

${ }^{140}$ Designação que não está isenta de críticas: a propósito do "constitucionalismo multinível", vd. Häberle (2009, p. 204-205).

${ }^{141} \mathrm{Vd}$. a informação disponível em https://www.coe.int/en/web/human-rights-rule-of-law/covid19. ${ }_{142}$ Art. 5. $\%$ /1/e) CEDH.

${ }^{143}$ Art. 15./1 CEDH. Meyer-Ladewig; Nettesheim; Raumer (2017). Especificamente sobre a questão do coronavírus à luz da CEDH, vd., em Portugal, Martins (2020).

${ }^{144}$ Carta de Direitos Fundamentais da União Europeia, art. 35. (Proteção da saúde): “Todas as pessoas têm o direito de aceder à prevenção em matéria de saúde e de beneficiar de cuidados médicos, de acordo com as legislações e práticas nacionais. Na definição e execução de todas as políticas e ações da União é assegurado um elevado nível de proteção da saúde humana".

${ }^{145} \mathrm{Vd}$. também o art. 6.ํㅜ TFUE: "A União dispõe de competência para desenvolver ações destinadas a apoiar, coordenar ou completar a ação dos Estados-Membros. São os seguintes os domínios dessas ações, na sua finalidade europeia: a) Proteção e melhoria da saúde humana".

146 “5. O Parlamento Europeu e o Conselho, deliberando de acordo com o processo legislativo ordinário, e após consulta ao Comité Económico e Social e ao Comité das Regiões, também podem adotar medidas de incentivo destinadas a proteger e melhorar a saúde humana, e nomeadamente a lutar contra os grandes flagelos transfronteiriços, medidas relativas à vigilância das ameaças graves para a saúde com dimensão transfronteiriça, ao alerta em caso de tais ameaças e ao combate contra as mesmas, bem como medidas que tenham por objetivo direto a proteção da saúde pública relativamente ao tabagismo e ao alcoolismo, com exclusão da harmonização das disposições legislativas e regulamentares dos Estados-Membros".

${ }^{147}$ Scott Greer/ Anniek de Ruijter (2020, p. 1).

148 Seitz (2020, p. 450).

149 Regulamento (CE) n. ${ }^{\circ}$ 851/2004, do Parlamento Europeu e do Conselho, de 21 de abril, que cria um Centro Europeu de Prevenção e Controlo das Doenças. 
vigilância epidemiológica e de controlo das doenças transmissíveis ${ }^{150}$, incluindo o Sistema de Alerta Rápido e de Resposta (EWRS - Early Warning and Response System). A Decisão n. ${ }^{\mathrm{o}}$ 1082/2013 ${ }^{151}$, que menciona expressamente o n. 5 do art. 168. , reforçou esse processo, sendo certo que estamos a falar de troca de informação, cabendo aos Estados Membros adotar as medidas necessárias. Prevêse ainda um papel para o Comité de Segurança da Saúde, com vista a "coordenar os (...) esforços [da Comissão e dos Estados-Membros] no sentido de desenvolver, reforçar e manter as suas capacidades de monitorização, alerta rápido, avaliação e resposta a ameaças transfronteiriças graves para a saúde" ${ }^{152}$. Há até instrumentos com impacto na contratação pública de contramedidas médicas (desde logo, vacinas contra as pandemias), permitindo que possa ser conjunta ${ }^{153}$, já considerados insuficientes, contrapondo-se a necessidade de uma "obrigação de solidariedade" neste campo ${ }^{154}$.

$\mathrm{Na}$ atual pandemia, em 2020, são diversas as intervenções da União ${ }^{155}$. Além disso, o Regulamento n. ${ }^{\circ}$ 1008/2008, do Parlamento Europeu e do Conselho, de 24 de setembro, relativo a regras comuns de exploração dos serviços aéreos na União, serviu de alicerce às restrições de $\operatorname{voos}^{156}$. Acresce que os artigos 25..$^{\circ}$ e 27. do Código de Fronteiras Schengen, aprovado pelo Regulamento (UE) 2016/399, do Parlamento Europeu e do Conselho, de 9 de março de 2016, também foram

${ }^{150}$ Decisão n.. 2119/98/CE, do Parlamento Europeu e do Conselho, de 24 de setembro, que institui uma rede de vigilância epidemiológica e de controlo das doenças transmissíveis.

${ }^{151}$ Decisão n. ${ }^{\circ}$ 1082/2013/UE do Parlamento Europeu e do Conselho, de 22 de outubro, relativa às ameaças sanitárias transfronteiriças graves e que revoga a Decisão n. ${ }^{\circ}$ 2119/98/CE. Vd. também o relatório da Comissão ao Parlamento Europeu e ao Conselho (Relatório sobre a aplicação da Decisão n.․ 1082/2013/UE do Parlamento Europeu e do Conselho, de 22 de outubro de 2013, relativa às ameaças sanitárias transfronteiriças graves e que revoga a Decisão n.. $2119 / 98 / C E$ ).

152 Arts. 4. ${ }^{\circ} / 1$ da Decisão n. ${ }^{\circ}$ 1082/2013/UE.

${ }^{153}$ Art. 5. ${ }^{\circ}$ da Decisão n. ${ }^{\circ} 1082 / 2013 /$ EU.

${ }^{154}$ Scott Greer/ Anniek de Ruijter (2020, p.1).

${ }^{155}$ Declaração da Comissão na sequência da apresentação da Diretiva (UE) 2020/739 da Comissão ao Parlamento Europeu e ao Conselho, no que diz respeito à prevenção e à proteção da saúde e da segurança dos trabalhadores que estão ou podem estar profissionalmente expostos ao SARS-CoV2 (2020/C 212/03); Diretiva (UE) 2020/739 da Comissão, de 3 de junho; que altera o anexo III da Diretiva 2000/54/CE do Parlamento Europeu e do Conselho no que diz respeito à inclusão do SARS-CoV-2 na lista de agentes biológicos reconhecidamente infeciosos para o ser humano e que altera a Diretiva (UE) 2019/1833 da Comissão; Regulamento de Execução (UE) 2020/402 da Comissão, que sujeita a exportação de determinados produtos à apresentação de uma autorização de exportação (14 de março), alterado pelo Regulamento de Execução (UE) 2020/426 (19 de março).

${ }_{156}$ Mais precisamente o art. 21.․ Vd. Despacho n.. $3186-\mathrm{D} / 2020$ (Suspensão de voos de Itália), de 10 de março, e Despacho n. . 3186-C/2020 (Suspensão de voos das zonas de Itália mais afetadas Emilia-Romagna, Piemonte, Lombardia e Veneto), também de 10 de março. A suspensão prevista no Despacho n. ${ }^{-}$3186-D/2020, de 10 de março, foi prorrogada ao longo do tempo por via dos Despachos n.os 3659-B/2020, de 23 de março, 4328-D/2020, de 8 de abril, 4808-B/2020, de 21 de abril, 5298-A/2020, de 5 de maio, e 5638-B/2020, de 20 de maio. 
convocados aquando da reposição, a título excecional e temporário, do controlo de pessoas nas fronteiras ${ }^{157}$.

Outros aspetos, como a "complementaridade dos (...) serviços de saúde nas regiões fronteiriças" e, em geral, a cooperação entre sistemas de saúde, assumem relevância.

Não versaremos aqui a questão da tutela de dados, domínio onde importa relembrar o marco que é o Regulamento Geral de Proteção de Dados ${ }^{158}$. Há ainda outras dimensões que se prendem com as consequências na saúde económica (e não vamos tratar de soluções, como um "keynesianismo pandémico" ${ }^{159}$ ) que tornaram "ativos estratégicos da Europa" vulneráveis ao controlo por entidades externas à União Europeia. Neste ponto, por exemplo, registe-se a intervenção da Comissão Europeia que estabeleceu um conjunto de linhas diretoras na matéria ${ }^{160}$.

\section{EM RITMO DE CONCLUSÃO}

Em tempo de profunda incerteza, de "sociedade(s) insegura(s)", vemos bens fundamentais serem afetados por um conjunto de males. Não é aqui o lugar para desenvolver uma "história alternativa" do direito constitucional a partir do(s) mal(es) e da(s) violência(s) ${ }^{161}$. No processo de hominização, a violência desenvolvida a partir de uma intensificação da rivalidade mimética instituiu o sagrado, por via do mecanismo do bode expiatório, estabelecendo-se crenças (mitos), práticas (ritos) e interditos (proibições) ${ }^{162}$. Na modernidade, assinalam-se processos de "migração do sagrado" ${ }^{163}$, tipicamente para o Estado e para a economia. O constitucionalismo moderno procurou responder a várias

\footnotetext{
157 Resolução do Conselho de Ministros n.o 10-B/2020, de 16 de março, que repõe, a título excecional e temporário, o controlo de pessoas nas fronteiras no âmbito da situação epidemiológica provocada pelo novo Coronavírus SARS-CoV-2 e da doença COVID-19, prorrogada pela Resolução do Conselho de Ministros n.. 22/2020, de 14 de abril, pela Resolução do Conselho de Ministros n. ${ }^{\circ}$ 33-B/2020, de 30 de abril, pela Resolução do Conselho de Ministros n. ${ }^{\circ}$ 34-A/2020, de 13 de maio e pela Resolução do Conselho de Ministros n. ${ }^{-0}$ 43-A/2020, de 12 de junho.

158 Regulamento (UE) 2016/679 do Parlamento Europeu e do Conselho, de 27 de abril de 2016, relativo à proteção das pessoas singulares no que diz respeito ao tratamento de dados pessoais e à livre circulação desses dados e que revoga a Diretiva 95/46/CE (Regulamento Geral sobre a Proteção de Dados).

159 Encontrámos a expressão em Shai Mulinari, num panorama da situação gerada pela pandemia e dirigida a quatro sociólogos: Danielsson; Liljeros; Mulinari; Soneryd (2020, p. 69).

${ }^{160}$ Comunicação da Comissão, Orientações para os Estados-Membros relativas a investimento direto estrangeiro e livre circulação de capitais provenientes de países terceiros, e proteção dos ativos estratégicos da Europa antes da aplicação do Regulamento (UE) 2019/452 (Regulamento Análise dos IDE) 2020/C 99 I/01, C/2020/1981, de 25/3/2020; Sahin (2020); tem-se como quadro jurídico, em relação às empresas relevantes para a segurança, o Regulamento (EU) 2019/452.

${ }^{161}$ No plano da filosofia e limitado à modernidade, vd. Neiman (2015).

162 É este um eixo fundamental da leitura proposta por René Girard: cf. o glossário constante de Cowdell; Fleming; Hodge (2014, p. 264-265).

163 Pensamos aqui no impressivo título de obra de Cavanaugh (2011, p. 4).
} 
violências ${ }^{164}$ : em primeiro lugar, garantindo a preservação da vida e de outros bens (a propriedade no sentido lockiano), através da segurança, limitando o próprio Estado, segundo a medida do direito; de acordo com a igualdade, pretendeu eliminar a violência da exclusão política, adjetivando o Estado como democrático; em registo de socialidade almejou uma igualdade real, capaz de libertar o ser humano da "angústia da existência"165, permitindo o acesso a um conjunto de bens essenciais para o "florescimento" (o desenvolvimento integral da pessoa humana) por via de um Estado ou de uma comunidade sociais; em chave de reconhecimento, procurou lidar com a diversidade, fazendo do reconhecimento da diferença do outro um aspeto fundamental, buscando eliminar a violência do desprezo ${ }^{166} \mathrm{em}$ função de certas notas; tendo como motivo-diretor a "sociedade de conhecimento", responder à violência da ignorância ${ }^{167}$ (não apenas a resultante da arcana praxis).

Falando de SARS-CoV-2, poderíamos pensar que estamos apenas perante uma "violência da natureza", simbolicamente ilustrada no terramoto de Lisboa e correntemente contraposta a Auschwitz, expressão da maldade humana ${ }^{168}$. No entanto, esta oposição entre os reinos da natureza e da liberdade, que não tem a clareza do desenho kantiano ${ }^{169}$, foi questionada, precisamente, na discussão travada em torno da catástrofe de 1 de novembro de 1755 . É célebre a polémica entre Voltaire e Rousseau ${ }^{170}$, tendo o último recusado a tese de que a ré fosse apenas a natureza. Seria imputável aos homens a concentração, num mesmo espaço, de 20.000 casas com vários pisos; ou seja, diríamos hoje que as consequências da catástrofe foram agravadas por disparates urbanísticos ${ }^{171}$. Rousseau veio abrir aqui o campo para uma "antropodiceia" ${ }^{172}$, uma responsabilização do homem,

164 Não é possível desenvolver aqui uma tipologia da(s) violência(s). Tomou-se em conta o contributo de Willke (1992) e a sua receção, entre nós, por Canotilho (2002, esp. 710-711).

165 Canotilho (2003, p. 249), baseando-se em Podlech.

166 Honneth (1997) fala de "formas de menosprezo", mas com um alcance mais amplo do que o assumido no nosso texto.

${ }^{167}$ Canotilho refere um "Estado de ciência e de saber" (711).

168 Jonas (1987, p. 44).

${ }^{169}$ Sobre este ponto, cf. Schwager (2006, p. 5-6, 117-118). No entanto, em rigor, esta crítica é distinta da referida no corpo deste artigo, pois centra-se na ideia de "organismo como memória" (p. 117) e na questão dos chamados "acidentes congelados" (Francis Crick) no quadro do processo de evolução. Já no texto põe-se o problema de saber, como resulta do título do artigo de Dupuy (2006), se "Ainda há catástrofes naturais?".

${ }^{170}$ Que, aliás, tratámos na nossa dissertação de doutoramento (Loureiro, 2003, Parte II, Cap. III).

${ }^{171}$ Colhemos a informação em Bayertz $(1995,50)$.

${ }_{172}$ Dupuy (2005, p. 57), citando uma formulação de Vladimir Jankélévitch (Le Je-ne-sais-quoi et le presque rien, Paris, Seuil, 1981). Leibniz cunhou o termo teodiceia, que tem como problema diretor a justificação da fé num Deus (bom, omnipotente e omnisciente) perante a existência do mal. Mal (malum) apresentado como o mal metafísico - a questão da finitude humana (a experiência da morte) -, mal moral (causado pelo homem) e mal físico (que encontramos na natureza): cf. Klaus von Stosch $(2013$, p. 9). 
sustentando, pois, que não fora a ação deste, os efeitos teriam sido muito menores no que toca à ceifa de vidas humanas.

Quanto ao coronavírus, a questão pode colocar-se logo na responsabilidade das autoridades chinesas ao permitirem que os mercados de animais vivos operassem em condições inadequadas (a confirmar-se que foi esta a origem), para além da discussão sobre o cumprimento ou não, por parte da República Popular da China, das obrigações decorrentes do Regulamento Sanitário Internacional ${ }^{173}$. Mas, do ponto de vista das outras sociedades, há que analisar a precaução e as medidas de resposta, sendo que, salvo situações gritantes de omissão de medidas, nos movemos mais no campo da responsabilidade política do que jurídica.

No entanto, perante a catástrofe, a perspetiva cooperativa e interconstitucional vê-se abalada por várias tentações. Desde logo, a panótica, levando mais longe a ideia de um "homem transparente" e uma sociedade de controlo. Esta é a ameaça presente, não o pan-europeísmo ${ }^{174}$ ou mesmo o panmundialismo. Ou seja, a importância das instituições, entre as quais se consta o Estado, mas que não esgota o panorama, não deve abrir as portas ao neoestatismo (no extremo, panótico), em tempo de "megadados" (Big Data), no limite, a um dobrar de sinos pelo constitucionalismo. Jeremy Bentham ${ }^{175}$ apresentou a ideia de panótico, de uma prisão com controlo absoluto, marcada por uma visão total, incluindo o interior das próprias celas. Na resposta à pandemia, não faltaram louvores à República Popular da China pelas suas medidas. Os chineses estão a utilizar as novas tecnologias com um elevadíssimo grau de intromissão nas liberdades, expressão de um projeto de controlo que recorda a distopia de Georges Orwell, 1984. A existência de uma constituição não é sinónimo de constitucionalismo. É verdade que não é só na

\footnotetext{
${ }^{173}$ Vd., por exemplo, Gostin; Habibi; Meier (2020). Convocando a boa-fé, vd. Pedro A. Villarreal (2020).

174 O pan-europeísmo não é aqui usado no sentido de um reforço de um "espaço jurídico europeu comum", assente num diálogo também doutrinário e jurisprudencial (para uma síntese, vd. Bogdandy; Grabenwarter; Huber, 2020), mas pretende referir-se à solução que passaria pelos Estados Unidos da Europa, que já teve melhores dias. Em 1923, Richard Coudenhove-Kalergi publica uma obra sintomaticamente intitulada Pan-Europe, onde sustentava uma Europa Unida da Polónia a Portugal (p. 27). Lembra que a ideia de Estados Unidos da Europa é "muito antiga" (p. 39). Não traçando agora as diferentes etapas, recorda-se que o impulso pan-europeu para as soluções federalistas conheceu traduções constitucionais, em termos que não podemos aprofundar aqui.

175 Jeremy Bentham, Panopticon; or, the Inspection-House, London: T. Payne, 1791. O uso do termo multiplicou-se nas últimas décadas, na sequência de uma conhecida obra de Michel Foucault (2013). Sobre o panótico e as prisões, considerando os textos de Bentham e criticando "a inusitada frequência, muitas vezes, (...) sem grande propriedade" do termo, na sequência da obra de Foucault, vd. Beleza (2017).
} 
China que há perigo de um "panótico eletrónico"176, falando-se de um "modelo autoritário" de resposta ${ }^{177}$.

Estamos perante uma visão anticonstitucional ${ }^{178}$, não na aceção de oposição a uma certa constituição ou mesmo à existência de um texto constitucional formal, mas de recusa de ideias estruturantes que marcam o constitucionalismo ocidental, a saber: a efetiva garantia dos direitos fundamentais e o princípio da divisão de poderes. A propósito da difusão do vírus em Wuhan, Žižek ${ }^{179}$ recorda a perseguição ao médico Li Wenliang e socorre-se de uma jornalista chinesa para lembrar a importância dos direitos do homem e como a história poderia ter sido outra, se na China fossem garantidas as liberdades, nomeadamente a liberdade de expressão.

Aliás, noutras sociedades, constitucionalmente, serviu também de chave para abrir portas de reforço do poder executivo, não como modo transitória e ditado pela necessidade de reagir à calamidade, mas como projeto político iliberal (entendida a expressão em termos de profunda restrição de direitos). Ou seja, há sempre o perigo do estado (em alemão, Zustand) de exceção se converter num Estado (Staat, no germânico idioma) de Exceção.

Perante um mal natural, mas cujo contágio foi tecnologicamente potenciado, ressalta desde logo, a violência sobre a corporeidade. Se a fragilidade é nota da nossa condição humana (para alguns, em termos agravados, falando-se de vulnerabilidade) ${ }^{180}$, também na circunstância marcada pela pandemia e pelas suas consequências, importa traçar linhas que tomem em consideração contributos jurídicos para (alguns) temas em discussão. Com efeito, o direito em geral e o direito constitucional em especial têm uma importante função de garantia e de limitação da(s) violência(s). Do ponto de vista das posições jurídicas, importa, no entanto, que os direitos não obnubilem os deveres quer das pessoas quer do Estado (em termos de deveres proteção e prestação).

Há uma solução mais radical que tem vindo a ganhar fôlego e que passa por eliminar a fragilidade da condição humana, através de otimização (transumanismo) ou, no limite, da superação do ser humano (pós-humanismo). Ou seja, não se trata de modificações no plano normativo ou organizacional, num tempo de "Estado nervoso"181, mas de superar o próprio homem, um dizer-lhe adeus, por vias que passam pela hibridação ou pela pura robotização. A condição

176 Hung (2009, p. 141, citando David Lyon, The electronic eye: the rise of surveillance society, Cambridge: Polity Press, 1994).

177 Nyamutata (2020, p. 75-78).

178 Sobre as várias aceções de anticonstitucionalismo, permitimo-nos remeter para Loureiro (2018).

179 Žižek (2020, p. 7).

180 Para a diferença entre fragilidade e vulnerabilidade, vd. Loureiro (2017).

${ }^{181}$ Para nos socorrermos da recente obra (que só parcialmente pôde ser considerada) de Barczak (2020). 
humana seria o mal, produto de acaso, sendo desejável o "desnascimento"182, a abolição da pessoa humana. Esta forma mais radical inscreve-se, por ora, num horizonte de (dis)(u)topia, apresentando-se como uma outra forma de antihumanismo, a partir de uma desmesurada confiança na técnica.

Tendo presente que as constituições brasileira e portuguesa, como muitas outras, assumem como princípio fundante a dignidade da pessoa humana ${ }^{183}$, urge antes prosseguir outro caminho: o da garantia de um acesso universal a bens sociais fundamentais, de uma verdadeira efetivação de uma "reserva do necessário"184 num mundo onde importa tomar a sério a escassez e não perder de vista a realidade que existe para lá do discurso e da linguagem. A relativa ${ }^{185}$ "indiferenciação" em termos de espaço - com a (neo)globalização, afetados podemos ser todos, pois as fronteiras não são barreiras ao vírus - e de sujeitos - o vírus não faz aceção de pessoas, tocando ricos e pobres, por exemplo - torna claro que, além de um fundamento que assenta numa ideia de justiça - a própria sobrevivência e a segurança apontam para a necessidade de efetivação desses direitos. Desde logo, ao nível mundial - uma via tortuosa, atendendo às diferenças, que não assentam apenas em disparidades em termos de ordem económica mundial, mas também em culturas (basta pensar na corrupção ${ }^{186}$, que já Pessoa classificava de vírus ${ }^{187}$ ) e em estruturas políticas (no limite, assentes numa lógica de "mal comum"188) -, fazendo dos Objetivos de Desenvolvimento Social (ODS) ${ }^{189}$ roteiro de percurso difícil e longo. Mas também no plano interno, onde quer em países do Norte do Norte (por exemplo, Alemanha) quer do Sul do Norte (Portugal), se descobre que a pobreza espelhada em habitações sem condições ${ }^{190}$ e a necessidade de circular em transportes públicos, dificultando ou inviabilizando o distanciamento social, são fatores que aceleram o contágio, com consequências que afetam muitos mais, mesmo os que não são infetados. Basta pensar nos fortíssimos impactos económicos

182 Hadjdad (2015, p. 138-141), analisando as propostas de Michèle Causse e de Kevin Warwick.

Sobre este ponto, permitimo-nos remeter para Loureiro (2020).

${ }^{183}$ Em língua portuguesa, vd. a relevante obra de Sarlet (2019).

${ }^{184}$ Colhemos a expressão em Andrade (2012, p. 184).

${ }^{185}$ Como escrevemos acima e se pode ler agora, por exemplo, logo na "Presentación" do livro de Innerarity (2020, p. 25): "[s]e da la paradoja de que un riesgo que nos iguala a todos revela al mismo tiempo los desiguales que somos, provoca otras desigualdades $(\ldots)^{\prime \prime}$.

${ }^{186}$ Vd., com outras indicações, Eduardo Figueiredo (2019).

187 Fernando Pessoa (1986, p. 1146) fala de "sociedades eivadas de qualquer vírus corruptor".

${ }^{188} \mathrm{O}$ conceito de "mal comum" foi trabalhado por um assumido discípulo de Xavier Zubiri, Ignacio Ellacuría. Escreveu en "El mal común y los derechos humanos": [e]l mal común será aquel mal estructural y dinámico que, por su proprio dinamismo estructural, tiene la capacidad de hacer malos a la mayor parte de los que constituyen una unidad social" (documento datilografado datado de 21 de junho de 1989, uns meses antes do seu assassinato).

189 Sobre os Objetivos de Desenvolvimento Social, vd. https://nacoesunidas.org/pos2015/.

190 A situação é mais grave noutros países: vd., por exemplo, o impressivo artigo de Staunton; Swanepoel; Labuschagine (2020) sobre o caso sul-africano, nomeadamente as habitações sem água canalizada. 
resultantes de, por exemplo, um país não ser considerado um destino seguro para efeitos turísticos. Abrem-se portas a desordens em diferentes campos ou esferas da vida. Numa "sociedade mundial de risco", a segurança, enquanto elemento da nova trilogia de que fala Ehrard Denninger ${ }^{191}$, assume centralidade, abraçando a solidariedade e exigindo uma efetiva realização da socialidade, que tome em atenção a diversidade das sociedades, nomeadamente a existência de comunidades que requerem uma especial atividade de mediação da informação.

Ainda aqui, e sem prejuízo da dimensão polemológica da política ${ }^{192}$, pretendese um caminho marcado por uma justiça "centrada em realizações"193, que, numa perspetiva constitucional, se foque, como dissemos, na garantia efetiva (e não só discursiva) da "reserva do necessário" mais do que na "reserva do possível", reduzindo violências a que, também por via de exclusão, estão sujeitos muitos seres humanos.

Em registo de memória, de um privilegiado confinamento desconfinado pelas asas do pensamento e da leitura, do diálogo batucado pelos prodígios do ciberespaço, abraça-nos a poesia de Mario Quintana ${ }^{194}$, que serviria para retratar algumas das paisagens em tempos de pandemia:

“Não passa ninguém. Apenas

Um gato

Atravessa a rua

Como nos tempos quase imemoriais

Do cinema silencioso...".

Simplesmente, ao contrário do título do poema, não é uma "Carta desesperada", mas a esperança (ir?)realista de abrirmos outros caminhos, num planeta crescentemente interdependente, coberto por um "manto (normativo) do mundo". Esperamos que o estado de exceção não vire Estado(s) de Exceção, opressor(es) da(s) liberdade(s), como pandemia que corrói pessoas e instituições, onde, como na Pasárgada de Manuel Bandeira ${ }^{195}$, é bom ser amigo do rei. Dobrando os sinos pela

191 Denninger (1994); também as análises constantes de Bizer; Koch (1998). Na doutrina portuguesa, para além da nossa receção [Loureiro (1999, p. 302); (2001, p. 845), vd. também Andrade (2019, p. 61); (2006, p. 132-141); mais recentemente, Moniz (2017, p. 252); para a sua aplicação à esfera internacional, Rangel (2002, p. 829-842), também em Rangel (2009, p. 107-123); Loureiro (2006, p. 190-196).

192 Esta dimensão polemológica - de conflito - da política tem sido sublinhada por um conjunto de autores situados em diferentes pontos do espetro político. Sem analisar agora Carl Schmitt e a contraposição entre amigo (Freund)/ inimigo (Feind) [cf. Schmitt (2015, p. 50-51)], recorde-se Chantal Mouffe (2019), que reafirma a defesa de uma "conceção agonística da democracia", ou Erhard Denninger [por exemplo, a síntese em Denninger (2007, p. 31-46)].

193 Sen (2012, p. 44-45).

${ }^{194}$ Quintana (2011, p. 70).

195 Bandeira (2001, p. 49-50). 
embriaguez das utopias - ainda que em vestes de "retrotopias"196 _, não podemos ignorar, desde logo do ponto de vista da sustentabilidade, as ameaças apocalíticas (de destruição) que são nuvens no horizonte das nossas existências, em termos pessoais e comunitários. Como cidadãos (e como) juristas, resta-nos procurar retomar o sentido etimológico de apocalipse e ajudar a desvelar, a tirar o véu. Conseguiremos, ainda que modestamente, contribuir para reforçar as dimensões catecónicas ${ }^{197}$ (de travão) e limitar a violência? Esta é uma tarefa histórica dos constitucionalismos. Mas, quanto ao futuro, o excesso do cristal e da(s) incerteza(s) enevoa a bola.

\section{REFERÊNCIAS}

AGAMBEN, Giorgio. Estado de excepção. Lisboa: Edições 70, 2010 (há ed. brasileira: Estado de exceção. Rio de Janeiro: Boitempo, 2004).

AGAMBEN, Giorgio. Reflexões sobre a peste: ensaios em tempo de pandemia. Rio de Janeiro: Boitempo, 2020.

AGINAM, Obijiofor. Mission (im)possible? The WHO as a 'norm entrepreneur' in global health governance". In: Michael Freeman; Sarah Hawkes; Belinda Bennett (ed.). Law and global health: current legal issues. Oxford: Oxford University Press, 2014.

ANDRADE, José Carlos Vieira de. Algumas reflexões sobre os direitos fundamentais, três décadas depois. Anuário Português de Direito Constitucional 5 (2006), p. 121-141.

ANDRADE, José Carlos Vieira de. Conclusões. In: Tribunal Constitucional, $35 .^{\circ}$ Aniversário da Constituição de 1976. Vol. I, Coimbra: Coimbra Editora, 2012, p. 175-189.

ANDRADE, José Carlos Vieira de. Os direitos fundamentais na Constituição Portuguesa de 1976. 6. Ed. Coimbra: Almedina, 2019.

APEL, Karl-Otto. Estudos de moral moderna. Petrópolis, RJ: Vozes, 1994.

\footnotetext{
196 Bauman (2017).

197 Não é este o lugar para o desenvolvimento destes topos, muito caro a Carl Schmitt. Aqui é usado na aceção de uma "função de travão" ou de "retardamento" (Verzögerung).
} 
BANDEIRA, Manuel. Vou-me embora pra Pasárgada. In: Italo Moriconi (org.). Os cem melhores poemas brasileiros do século. Rio de Janeiro: Objetiva, 2001, p. 4950 .

BARCZAK, Tristan. Der nervöse Staat: Ausnahmezustand und Resilienz des Recht in der Sicherheitsgesellschaft, Tübingen: Mohr Siebeck, 2020.

BAUMAN, Zygmunt. Retrotopia. Polity: Cambridge, 2017 (há trad. bras.: Rio de Janeiro: Zahar, 2017).

BAYERTZ, Kurt. “Eine kurze Geschichte der Herkunft der Verantwortung”. In: Idem (Hrsg.), Verantwortung: Prinzip oder Problem?. Darmstadt:

Wissenschaftliche Buchgesellschaft, 1995, p. 3-71.

BECK, Ulrich. Risikogesellschaft: auf dem Weg in eine andere Moderne. Frankfurt a. M.: Suhrkamp, 1986.

BECK, Ulrich. ¿Qué es globalización?: falacias del globalismo, respuestas a la globalización. Barcelona; Buenos Aires; México, 1998.

BECK, Ulrich. Politik in der Risikogesellschaft. Frankfurt a. M.: Suhrkamp, 1991.

BECK, Ulrich. Weltrisikogesellschaft: Auf der Suche nach der verlorenen Sicherheit. Frankfurt a. M.: Suhrkamp, 2007.

BELEZA, José Manuel Merêa Pizarro. O estribilho do Panóptico. In Estudos em Homenagem ao Prof. Doutor Manuel da Costa Andrade, Vol. I, Direito Penal, Coimbra: Instituto Jurídico, 2017, p. 149-175.

BENTHAM, Jeremy. Panopticon; or, the Inspection-House. London: T. Payne, 1791.

BIRNBACHER, Dieter. Grenzen der Verantwortung, in Kurt Bayertz (Hrsg.), Verantwortung: Prinzip oder Problem?. Darmstadt: Wissenschaftliche Buchgesellschaft, 1995, p. 143-183.

BIZER, Johannes; KOCH, Hans-Joachim (Hrsg.). Sicherheit, Vielfalt, Solidarität: ein neues Paradigma des Verfassungsrechts? Symposium zum 65. Geburtstag Erhard Denningers am 20. Juni 1997. Baden-Baden: Nomos, 1998. 
BOBBIO, Norberto. A era dos direitos. 7. Reimp. Rio de Janeiro: Elsevier Editora, 2004.

BÖCKENFÖRDE, Ernst-Wolfgang. The repressed state of emergency: the exercise of state authority in extraordinary circumstances. In: Constitutional and political theory: selected writings. Oxford: Oxford University Press, 2017, Vol. I, p. 108-132.

BOGDANDY, Armin von; GRABENWARTER, Christoph; HUBER, Peter. Constitutional adjudication in the European Legal Space. In: The Max Planck Handbooks in European Public Law: Volume III: Constitutional adjudication: institutions. Oxford: Oxford University Press, 2020.

BRITO, Miguel Nogueira de. Modelos de emergência no direito constitucional. e-Pública 7 (2020/1), p. 6-27.

CAETANO, Marcello. Manual de direito administrativo. 9 Ed. t. II, Lisboa, 1972.

CALABRESI, Guido; BOBBITT, Philip. Tragic choices: the conflicts society confronts in the allocation of tragically scarce resources. New York; London: W.W. Norton \& Company, 1978.

CANOTILHO, José Joaquim Gomes. O direito constitucional passa; o direito administrativo passa também. In: Estudos em Homenagem ao Prof. Doutor Rogério Soares. Coimbra: Coimbra Editora, 2002, p. 705-722.

CANOTILHO, José Joaquim Gomes. Direito constitucional e teoria da constituição. 7 Ed. Coimbra: Almedina, 2003.

CANOTILHO, José Joaquim Gomes. Dos direitos individuais ao direito à paz: entre a paz perpétua e a tópica jurídica. Boletim da Faculdade de Direito 84 (2008), p. 25-33.

CANOTILHO, José Joaquim Gomes. Para um enquadramento constitucional das garantias de protecção judicial no direito público: breves notas. Scientia Iuridica 62 (2013), p. 325-374. 
Cavanaugh, William T. Migrations of the holy: God, state, and the political meaning of the church, Grand Rapids, Michigan; Cambridge, UK: Wm B. Eerdmans Publishing Co., 2011.

CHARDIN, Pierre Teilhard de. Sobre a felicidade, sobre o amor. Coimbra: Tenacitas, 2008.

CORREIA, António Damasceno. Estado de sítio e estado de emergência em democracia. Lisboa: Vega, 1989.

COSTA, José de Faria. A linha (Algumas reflexões sobre a responsabilidade em um tempo de 'técnica' e de 'bio-ética'). In: O homem e o tempo: liber amicorum para Miguel Baptista Pereira. Porto: Fundação Eng. António de Almeida, 1999, p. 397-411.

COUDENHOVE-KALERGI, Richard. Pan-Europe. Wien: Pan-Europa Verlag, 1923 (reimp.: 1982).

COWDELL, Scott; FLEMING, Chris; HODGE, Joel (ed.). Violence, desire, and the sacred, Vol. I: Girard's mimetic theory across the disciplines, New York; London, 2014.

CRUZ VILLALÓN, Pedro. Estados excepcionales y suspensión de garantías. Madrid: Tecnos, 1984.

D'ARCAIS, Paolo Flores. Filosofia e virus: le farneticazioni di Giorgio Agamben. Micromega (http://temi.repubblica.it/micromega-online/filosofia-e-virus-lefarneticazioni-di-giorgio-agamben/).

DANIELSSON, Erna; LILJEROS, Fredrik; MULINARI, Shai; SONERYD, Linda.

Sociologiska perspektiv på coronakrisen: Fyra sociologer om samhällets reaktion på covid-19. Sociologisk Forskning 57 (2020), p. 67-76.

DENNINGER, Erhard. Sicherheit/ Vielfalt/ Solidarität: Ethisierung der Verfassung? In: Ulrich K. Preuss (Hrsg.). Zum Begriff der Verfassung: die Ordnung des Politischen. Frankfurt a. M.: Fischer Taschenbuchverlag, 1994.

DENNINGER, Erhard. Derecho y procedimiento jurídico como engranaje en una sociedad multicultural. In: Erhard Denninger; Dieter Grimm. Derecho 
constitucional para la sociedad multicultural. Madrid: Editorial Trotta, 2007, p. 2750 .

DIAS, Eduardo Rocha. Direito à saúde e informação administrativa: o caso das advertências relativas a produtos perigosos. Belo Horizonte: Editora Fórum, 2008.

DUPUY, Jean-Pierre. Introdução às ciências sociais: lógica dos fenómenos coletivos. Lisboa: Instituto Piaget, 2001.

DUPUY, Jean-Pierre. Pour un catastrophisme éclairé: quand l'impossible est certain. Paris: Éditions du Seuil, 2002.

DUPUY, Jean-Pierre. Petite métaphysique des tsunamis. Paris: Seuil, 2005.

DUPUY, Jean-Pierre. Ainda há catástrofes naturais?. Análise social 41 (2006/181), p. 1181-1193.

EGÍDIO, Mariana Melo. Protecção de dados em tempos de COVID-19 - Breves reflexões. e-Pública 7 (2020/1), p. 184-199.

ELLACURÍA, Ignacio. El mal común y los derechos humanos (documento datilografado datado de 21 de junho de 1989; disponível em www.uca.edu.sv > uploads > 2015/03).

ENGISCH, Karl. Einführung in das juristische Denken. 9 Ed. Stuttgart; Berlin; Köln: Verlag W. Kohlhammer, 1997.

EPPING, Volker. In: Maunz; Dürig, Grundgesetz-Kommentar. München: Beck, 2012.

FERRAJOLI, Luigi. Constitucionalismo más allá del Estado. Madrid: Editorial Trotta, 2018

FERRAJOLI, Luigi. Manifesto per l'uguaglianza. Bari; Roma: Editori Laterza, 2019.

FERRAJOLI, Luigi. Perchè una costituzione della Terra?. 20/2/2020, http://www.costituenteterra.it/perche-una-costituzione-della-terra/. 
FIDLER, David P. SARS, governance and the globalization of the disease. New York: Palgrave, 2004.

FIGUEIREDO, Eduardo. O princípio anticorrupção e o seu papel na defesa e efetivação dos direitos humanos. Jundiaí, São Paulo: Ed. in House; Ed. Brasílica, 2019.

FISCHER, Edgar; DIETERICH, Peter. Prüfungsrecht in Zeiten der CoronavirusPandemie". Neue Zeitschrift für Verwaltungsrecht (2020) p. 657-665.

FORSTHOFF, Ernst. El Estado de la sociedad industrial. Madrid: Instituto de Estudios Políticos, 1975.

FOUCAULT, Michel. Vigiar e punir: nascimento da prisão. Lisboa: Edições 70, 2013 (há edição brasileira: Petrópolis: Vozes, 1987).

FRATESCHI, Yara. Agamben sendo Agamben: o filósofo e a invenção da pandemia. (https://blogdaboitempo.com.br/2020/05/12/agamben-sendo-agambeno-filosofo-e-a-invencao-da-pandemia/).

FREITAS, Tiago Fidalgo de. A execução do estado de emergência e da situação de calamidade nas Regiões Autónomas - o caso da pandemia COVID-19. ePública 7 (2020/1), p. 44-77.

GARCIA, Maria da Glória. O lugar do direito na protecção do ambiente. Coimbra: Almedina, 2007.

GÄRDITZ, Klaus Ferdinand; ABDULSALAM, Maryam Kamil. Rechtsverordnungen als Intrument der Epidemie-Bekämpfung. Zeitschrift für das Gesamte Sicherheitsrecht (2020/3), p. 93-140.

GILL, Stephen. Market civilization, new constitutionalism and world order. In: Stephen Gill/ A. Claire Cutler (eds). New Constitutionalism and World Order. Cambridge: Cambridge University Press, 2014, p. 29-44.

GIRARD, René. Achever Clausewitz: entretiens avec Benoît Chantre. Paris: Flammarion, 2011. 
GLAAB, Sarah; SCHWEDLE, Anna. Besuchseinschränkungen in Pflegeheimen zur Bekämpfung des Coronavirus. Neue Juristische Wochenschrift (2020), p. 1702-1705.

GONÇALVES, Pedro. Advertências da Administração Pública. In: Estudos em Homenagem ao Prof. Doutor Rogério Soares. Coimbra: Coimbra Editora, 2002, p. 723-796.

GONÇALVES, Pedro. Manual de direito administrativo. vol. 1, Coimbra: Almedina, 2019.

GONÇALVES, Pedro. Abdicação parlamentar na emergência e continuação da abdicação na calamidade. Observatório Almedina, 21 de maio de 2020, disponível em https://observatorio.almedina.net/index.php/2020/05/21/abdicacaoparlamentar-na-emergencia-e-continuacao-da-abdicacao-na-calamidade/).

GOSTIN, Lawrence O.; HABIBI, Roojin; MEIER, Benjamin Mason. Has global health law risen to meet the COVID-19 challenge? Revisiting the International Health Regulations to prepare for future threats. Journal of Law, Medicine \& Ethics (2020) (disponível em Georgetown Law Scholarly Commons https://scholarship.law.georgetown.edu/facpub/2264).

GOUVEIA, Jorge Bacelar de. O estado de excepção no direito constitucional. Coimbra: Almedina, 1999 (2 vol.).

GREER, Scott; de Ruijter, Anniek. EU health law and policy in and after the COVID-19 crisis. European Journal of Public Health (2020), p. 1-2.

GROß, Detlef. Die Produktzulassung von Novel Food: das Inverkehrbringen von neuartigen Lebensmitteln und Lebensmittelzutaten nach der Verordnung (EG) Nr. 258/97 im Spannungsfeld von Europa-, Lebensmittel- und Umweltrecht. Berlin: Duncker und Humblot, 2001.

HABERMAS, Jürgen. Die postnationale Konstellation: politische Essays. Frankfurt a. M.: Suhrkamp, 1998.

HABIBI, Roojin et al. Do not violate the International Health Regulations during the COVID-19 outbreak. The Lancet 395 (2020) p. 664-666.

HADJDAD, Fabrice. ¿Qué es una familia? La trascendencia en paños menores (y otras consideraciones ultrasexistas). Granada: Nuevo Inicio, 2015. 


\section{HÄBERLE, Peter. Kritik an der Metapher vom sogenannten}

"Mehrebenenkonstitutionalismus“- Diskussionsbeitrag auf der Tagung der Vereinigung der Deutschen Staatsrechtslehrer in Rostock vom 4. bis 7. In: Verfassungsvergleichung in Europa- und weltbürgerlicher Absicht: Späte Schriften. Berlin: Duncker \& Humblot, 2009.

HÄBERLE, Peter. Die “Kultur des Friedens" - Thema der universalen Verfassungslehre. Oder: Das Prinzip Frieden. Berlin: Duncker \& Humblot, 2017.

HÄBERLE, Peter; Lutz, Hans-Joachim. Gesetz zur Verhütung und Bekämpfung von Infektionskrankheiten beim Menschen (Infektionsschutzgesetz - IfSG): Kommentar. München: Beck, 2020.

HONNETH, Axel. La lucha por el reconocimiento: por una gramática moral de los conflictos sociales, Barcelona: Crítica, 1997.

HUNG, Chin-fu. The politics of the governing of the information and

communication technologies in East Asian Authoritarian States: case study of China. In: Francesco Amoretti (ed.). Electronic constitution: social, cultural, and political implications. Hershey; New York: Information Science Reference, 2009, p. 134-153.

ILLOUZ, Eva. Seven lessons of an unprecedented crisis. 2020 https://fallsemester.org/2020-1/2020/5/13/eva-illouz-seven-lessons-of-anunprecedented-crisis)

INNERARITY. Daniel. Presentación, In: Pandemocracia: una filosofía de la crisis del coronavirus. Barcelona: Galaxia Gutenberg, 2020, p. 23-26.

INNERARITY. Daniel. La democracia en Europa. Barcelona: Galaxia Gutenberg, 2017.

JONAS, Hans. Der Gottesbegriff nach Auschwitz: eine jüdische Stimme. Frankfurt am Main: Suhrkamp, 1987.

JONAS, Hans. O princípio responsabilidade: ensaio de uma ética para a civilização tecnológica. Rio de Janeiro: Contraponto; Editora PUC-Rio, 2006. 
JUREIT, Ulrike; TIETZE, Nikola (Hg.). Postsouveräne Territorialität: die Europäische Union und ihr Raum. Hamburg: Hamburger Ed., 2015.

KARAVOKYRIS, George. The coronavirus crisis-law in Greece: a (constitutional) matter of life and death. Verfassungsblog, 14 April 2020

(https://verfassungsblog.de/the-coronavirus-crisis-law-in-greece-a-constitutionalmatter-of-life-and-death/).

KEMP, Peter. Das Unersetzliche: eine Technologie-Ethik. Berlin: Wichern-Verlag, 1992.

KIEßLING, Andrea. Offene Fragen der (Massen)Quarantäne. Verfassungsblog 2/7/2020.

KLAFKI, Anika. Risiko und Recht: Risiken und Katastrophen im Effektivität, demokratischer Legitimation und rechtsstaatlichen Grundsätzen am Beispiel von Pandemien. Tübingen: Mohr Siebeck, 2017.

KNIGHT, Frank H. Risk, uncertainty and profit. 1921

(https://papers.ssrn.com/sol3/ papers.cfm?abstract_id=1496192).

KOUROUTAKIS, Antonios. "The emergency constitution of Greece: ideal on paper, inefficient in reality", http://www.iconnectblog.com/2016/03/theemergency-constitution-of-greece-ideal-on-paper-inefficient-in-reality/.

LARENZ, Karl. Metodologia da ciência do direito. 2 Ed. Lisboa: Fundação Calouste Gulbenkian, 1989.

LOUREIRO, João Carlos. O direito à identidade genética do ser humano. In: Portugal-Brasil Ano 2000. Coimbra: Coimbra Editora, 1999, p. 263-389.

LOUREIRO, João Carlos. Da sociedade técnica de massas à sociedade de risco: prevenção, precaução e tecnociência. Algumas questões juspublicísticas. In: Estudos em homenagem ao Prof. Doutor Rogério Soares. Coimbra: Coimbra Editora, 2001, p. 797-891.

LOUREIRO, João Carlos. Constituição e biomedicina: contributo para uma teoria dos deveres bioconstitucionais na esfera da genética humana, I. Coimbra, 2003. 
LOUREIRO, João Carlos. «É bom morar no azul»: a constituição mundial revisitada. Boletim da Faculdade de Direito 82 (2006), p. 181-212.

LOUREIRO, João Carlos. Direito à (proteção) da saúde. Revista da Defensoria Pública 1 (2008/1) 35-73.

LOUREIRO, João Carlos. Fiat constitutio, pereat mundus? Neojoaquimismo, constitucionalismo e escassez. Revista Portuguesa de Filosofia 70 (2014/2-3), p. 231-260.

LOUREIRO, João Carlos. Derecho a la protección de la salud y vulnerabilidad. Revista Iberoamericana de Bioética (2017/5) https://dialnet.unirioja.es/servlet/articulo?codigo=6170097.

LOUREIRO, João Carlos. Constituição social e(m) questão/questões: entre realismo e utopismo. Meditações de um pobre constitucionalista resistente num rico país. In: Olhar o constitucionalismo português nos 40 anos da Constituição de 1976. Coimbra: Instituto Jurídico, 2017a, p. 43-99.

LOUREIRO, João Carlos. Anticonstitucionalismo(s). In: José Eduardo Franco (Coord.). Dicionário dos Antis: a cultura portuguesa em negativo. Vol. 1. Lisboa: INCM, 2018, p. 434-439.

LOUREIRO, João Carlos. Constituição, escassez(es) e socialidade(s): entre a(s) realidade(s) e o(s) desejo(s) (texto de apoio). Coimbra, 2019 (uma versão revista deve ser publicada em 2021).

LOUREIRO, João Carlos. Sobre(s), trans(ces) y post(res): de la carne del nacimiento al ciber de la fabricación? Breves notas en torno a la tecnología, derechos(s) y cuerpo(s) en diálogo con Hannah Arendt. In: Antonio José Sanchéz Sáez (coord.). Dignidad y vida humana: eutanasia, gestación subrogada y transhumanismo. Aranzadi Thomson Reuters, 2020, p. 383-440.

MARTINS, Ana Maria Guerra. O impacto da COVID 19 nos direitos humanos: a resposta da Convenção Europeia dos Direitos Humanos. e-Pública 7 (2020/1), p. 153-169. 
MAYEN, Thomas. "Der verordnete Ausnahmezustand: Zur

Verfassungsmäßigkeit der Befugnisse des Bundesministeriums für Gesundheit nach § IFSG § 5 IfSG”. Neue Zeitschrift für Verwaltungsrecht (2020) 828-834.

MELO, António Barbosa de. As tensões entre bem pessoal e bem comum (um ponto de vista jurídico). In: CEB-AECEM/EACME, Bem da pessoa e bem comum: um desafio à bioética/ Bien de la personne et bien commun/ Individual wellbeing and common wellbeing, Coimbra: Gráfica de Coimbra, 1998, p. 25-36.

MELO, António Barbosa de. A incerteza na decisão em bioética: a visão de um jurista. Revista Portuguesa de Bioética (2007/2), p. 157-169.

METZ, Johann Baptist. Memoria passionis: una evocación provocadora en una sociedad pluralista. Santander: Editorial Sal Terrae, 2007.

MEYER-LADEWIG, Jens; NETTESHEIM, Martin; RAUMER, Stefan von (Hrsg.). EMRK: Europäische Menschenrechtskonvention: Handkommentar. BadenBaden: Nomos: Manz: Wien; Basel: Helbing Lichtenhahn Verlag, 2017.

MIRANDA, Jorge. Direitos fundamentais. 2 Ed. Coimbra: Almedina, 2017.

MONIZ, Ana Raquel. Os direitos fundamentais e a sua circunstância: crise e vinculação axiológica entre o Estado, a sociedade e a comunidade global. Imprensa da Universidade de Coimbra: Coimbra, 2017.

MORAES, Carlos Blanco de. O Estado de excepção. Lisboa: Cognitio, 1984.

MOUFFE, Chantal. Por um populismo de esquerda. Lisboa: Gradiva, 2019.

MÜLLER, Friedrich. Métodos de trabalho do direito constitucional. 3 Ed. Rio de Janeiro; São Paulo: Renovar, 2005.

NABAIS, José Casalta. O dever fundamental de pagar impostos: contributo para a compreensão constitucional do estado fiscal contemporâneo. Coimbra: Almedina, 1998.

NEGRI, Stefania. Communicable disease control. In: Gian Luca Burci; Brigit Toebes (ed.). Research Handbook on global health law. Cheltenham; Northampton: Edward Elgar Publishing, 2018, p. 265-302. 
NEIMAN, Susan. Evil in modern thought: an alternative history of philosophy. Princeton: Princeton University Press, 2015 (edição que inclui um posfácio não integrado na primeira, datada de 2002 e traduzida em português: O mal no pensamento moderno: uma história alternativa da filosofia, editada no Brasil $-\mathrm{S}$. Paulo: Difel, 2003 - e em Portugal - Lisboa: Gradiva, 2005).

NEVES, Marcelo. Transconstitucionalismo. São Paulo, 2009.

NOVAIS, Jorge Reis. Estado de emergência - Quatro notas jurídicoconstitucionais sobre o Decreto Presidencial. Observatório Almedina: https://observatorio.almedina.net/index.php/2020/03/19/estado-de-emergenciaquatro-notas-juridico-constitucionais-sobre-o-decreto-presidencial).

NYAMUTATA, Conrad. Do civil liberties really mattering during pandemics?. International Human Rights Law Review 9 (2020/1), p. 62-98.

PALAVER, Wolfgang. René Girard's mimetic theory. East Lansing: Michigan State University Press, 2013.

PAPIER, Hans-Jürgen. Freiheitsrechte in Zeiten der Pandemie. Deutsche Richterzeitung (2020). p. 180-183.

PESSOA, Fernando. Régie, monopólio, liberdade. In: Idem, Obra poética e em prosa. Vol III (Introdução, organização, biobliografia e notas de António Quadros). Lello \& Irmão: Porto, 1986, p. 1142-1153.

PIRES, Francisco Lucas. Introdução ao direito constitucional europeu, Coimbra: Almedina, 1997.

POTTAKIS, Andreas. Departing from the ordinary: the executive prerogative in a state of emergency. European Public Law 20 (2014/2), p. 181-194.

PREINER, Cristiano. La risposta istituzionale del governo Orbán alla pandemia da Coronavirus: dai poteri eccezionali alla revoca dello stato di pericolo. Nuovi Autoritarismi e Democrazie: Diritto, Istituzioni, Società (2020/1), p. 315-328.

QUAMMEN, David. Contágio: infeções de origem animal e a próxima grande pandemia. Carnaxide: Objectiva, 2020. 
QUINTANA, Mario. Quintana de Bolso: rua dos cataventos \& outros poemas. Porto Alegre: L\&PM, 2011.

RANGEL, Paulo. Diversidade, solidariedade e segurança (notas em redor de um novo programa constitucional). Revista da Ordem dos Advogados 62 (2002), p. 829-842.

RANGEL, Paulo. Uma teoria da «interconstitucionalidade»: pluralismo e Constituição no pensamento de Francisco Lucas Pires. Thémis (2000/2), p. 127-151.

RANGEL, Paulo. O estado do Estado: ensaios de política constitucional sobre justiça e democracia. Dom Quixote: Lisboa, 2009.

RANGEL, Paulo. Transconstitucionalismo versus interconstitucionalidade: uma leitura crítica do pensamento 'transconstitucional' de Marcelo Neves. In Tribunal Constitucional: 35. aniversário da Constituição de 1976. Coimbra: Coimbra Editora, 2012, p. 151-174.

REALE, Miguel. Teoria tridimensional do direito. Teoria da justiça. Fontes e modelos do direito. Lisboa: Imprensa Nacional-Casa da Moeda, 2003.

SAHIN, Samed R. Die Leitlinien der Europäischen Kommission zur Kontrolle ausländischer Direktinvestitionen in der COVID-19-Krise. COVuR (2020), p. 192-194.

SARLET, Ingo Wolfgang. Dignidade (da pessoa) humana e direitos fundamentais na Constituição Federal de 1988. 10 Ed. Porto Alegre: Livraria do Advogado Editora, 2019.

SCHIERA, Pierangelo. A polícia como síntese de ordem e de bem-estar no moderno Estado centralizado. In: António Manuel Hespanha. Poder e instituições na Europa do Antigo Regime: Colectânea de textos. Lisboa: Fundação Calouste Gulbenkian, 1984, p. 307-319.

SCHMITT, Carl. O conceito do político. Lisboa: Edições 70, 2015.

SCHMITZ, Peter. Smarte Bekämpfung der Pandemie ist datenschutzrechtlich erlaubt. ZD-Aktuell (2020) p. 4404. 
SCHWAGER, Raymund. Banished from Eden: original sin and evolutionary theory in the drama of salvation. Herefordshire: Gracewing, 2006.

SCHWAGER, Raymund. Gesammelte Schriften - Band 5 - Dogma und dramatische Geschichte: Christologie im Kontext von Judentum, Islam und moderner Marktkultur. Freiburg; Basel; Wien, 2014.

SEITZ, Claudia. Schutz vor Epidemien und Pandemien in der Europäischen Union. Europäische Zeitschrift für Wirtschaftsrecht (2020), p. 449-453.

SEN, Amartya. A ideia de justiça. Coimbra: Almedina, 2012 (há edição brasileira: São Paulo: Companhia das Letras, 2011).

SIEGEL, Thorsten. Verwaltungsrecht im Krisenmodus. Neue Zeitschrift für Verwaltungsrecht (2020) p. 577-583.

SILVA, Jorge Pereira da. Direitos fundamentais: teoria geral. Lisboa: Universidade Católica Portuguesa, 2018.

SILVA, Suzana Tavares da. Sustentabilidade e solidariedade em tempos de crise. In: José Casalta Nabais; Suzana Tavares da Silva (Coord.), Sustentabilidade fiscal em tempos de crise. Coimbra: Almedina, 2011, p. 61-91.

STAUNTON, Ciara; SWANEPOEL, Carmen; LABUSCHAGINE, Melodie. Between a rock and a hard place: COVID-19 and South Africa's response. Journal of Law and the Biosciences (2020).

STEHR, Nico. Die Freiheit ist eine Tochter des Wissens. Wiesbaden: Springer VS, 2015.

STOBER, Rolf; Eisenmenger, Sven. Katastrophenverwaltungsrecht - Zur Renaissance eines vernachlässigten Rechtsgebietes. Neue Zeitschrift für Verwaltungsrecht (2005) p. 121-130.

STOSCH, Klaus von. Theodizee. Paderborn, Ferdinand Schöningh, 2013.

THIELBÖRGER, Pierre; BEHLERT, Benedikt. COVID-19 und das Grundgesetz:Zur(Un)tauglichkeit des verfassungsrechtlichen „Immunsystems". Verfassungsblog 19/3/2020. 
TONTI, Lauren. The International Health Regulations: the past and the present, but what future?. Harvard International Law Journal (2020) (https://harvardilj.org/2020/04/the-international-health-regulations-the-past-andthe-present-but-what-future/).

URBANO, Maria Benedita. Estado de necessidade económica e financeira e o papel do Tribunal Constitucional. In: Pedro Gonçalves; Carla Amado Gomes; Helena Melo; Filipa Calvão (coord.). A crise e o direito público: VI Encontro de Professores Portugueses de Direito Público. Lisboa: Instituto de Ciências JurídicoPolíticas, 2013, p. 7-31.

VILLARREAL, Pedro A. The 2019-2020 novel coronavirus outbreak and the importance of good faith for international law. Völkerrechtsblog, 28, January 2020.

WILLKE, Helmut. Die Ironie des Staates: Grundlinien einer Staatstheorie polyzentrischer Gesellschaft. Frankfurt am Main: Suhrkamp, 1992.

ŽIŽEK, Slavoj. Pandemic! COVID-19 shakes the world. OR Books: New York/ London, 2020. 